\title{
An Assessment of Sustainable energy management at a Major Scandinavian Hub Airport: The Case of Oslo Airport Gardermoen
}

\author{
Glenn Baxter
}

School of Tourism and Hospitality Management, Suan Dusit University, Huahin Prachaup Khiri Khan, Thailand Email: g_glennbax@dusit.ac.th

Received: 01 Oct 2021; Received in revised form: 15 Dec 2021; Accepted: 23 Dec 2021; Available online: 30 Dec 2021 (C2021 The Author(s). Published by Infogain Publication. This is an open access article under the CC BY license (https://creativecommons.org/licenses/by/4.0/).

\begin{abstract}
Using on an in-depth qualitative instrumental case study research approach, this study has examined Oslo Airport Gardermoen sustainable energy management. The study period was from 2005 to 2020. The qualitative data was analyzed by document analysis. The airport purchases electricity and heating and cooling energy from external vendors. The non-renewable energy sources include aircraft jet fuel, heating oil/diesel, fuel and biofuels for the airport's vehicles, and supplies of paraffin/Jet A1 fuel and propane, with the latter fuel sources being used for the fire drills conducted at the airport. The case study found that throughout the study period Oslo Airport Gardermoen has implemented extensive energy conservation measures and technologies that have enabled the airport to mitigate its impact on the environment. The energy conservation measures include the extensive use of LED lighting, the replacement of a ventilation unit with a free cooling unit, an upgrade to the airport's heat exchanger, the introduction of more energy efficient rotary heat recovery units, and the replacement of flood lighting around the airport's terminal building with new LED lighting. The airport also installed blanking pedestals on the existing lights in Hangar 8. Other energy saving measures included the installation of motion sensors and night lowering in Pir Syd, the night lowering of lighting in Pier Norda and $S B V$, and the automatic control of ground heating systems at the airport's apron. A very important environmentrelated energy measure has been the use of sustainable aviation fuels. Oslo Airport was the world's first airport to offer sustainable jet biofuel to all airlines serving the airport.
\end{abstract}

Keywords-Airports, Case study, Energy, Energy saving measures, Oslo Airport Gardermoen, Sustainable airport energy management.

\section{INTRODUCTION}

Airports are quite unique entities that have substantial economic, social, and environmental impacts on local, regional, and often in many cases, national levels. However, there are both social and environmental costs associated with the construction and operation of airports (Culberson, 2011). The operations of airports have a variety of impacts on both local communities and the natural environment. These impacts include noise, local air quality issues, significant energy consumption, large water use, and the generation of wastes (Daley, 2016; Graham,
2018; Thomas \& Hooper, 2013). Airports located throughout the world are increasingly becoming environmentally concerned, and, as a result, have increased their efforts to reduce air transport impacts on the environment by applying environmental management, certification systems, or other forms of ecological rating systems to their infrastructures and operation (Comendador et al., 2019). Indeed, in recent times, the air transport industry has initiated new sustainability efforts in response to society's greater requirements for living in healthier and more sustainable environments (Monsalud et al., 2015). Accordingly, many airports have implemented 
strategies and initiatives to "green" themselves, that is, to become more sustainable in the medium to long-term (Janić, 2011; Kumar et al., 2020; Prosperi, 2009).

Airports are extremely energy intensive (Baxter et al., 2018a, 2018b; de Rubeis et al., 2016). Consequently, many airports are increasing their energy efficiency as part of their efforts to reduce their impact on the environment and, more broadly, on climate change (Preston, 2015). Indeed, airports are now under growing pressure to use energyefficient systems whilst also complying with increasingly stringent regulations. At the same time, airports are still required to provide occupant thermal comfort. Furthermore, energy efficiency enables airports to reduce their operating costs and reduce their carbon footprint (Taber \& Steele, 2020).

In addition, airports are no longer simply based on aviation related functionalities (for example, passengers, air cargo, and aircraft handling facilities), rather they have changed, and many airports now have shopping and hotel complexes, conference facilities, industrial zones, logistic centres as well as inter-modal public transport hubs (Ferrulli, 2016). Airports have become multimodal/functional businesses and have established significant commercial development both inside and outside of their boundaries (Reiss, 2007). Many airports have become true "airport cities" (Appold \& Kasarda, 2011; Efthymiou \& Papatheodorou, 2018; Orth \& Weidmann, 2014). These non-aviation facilities and their operations can increase the airport's energy requirements quite significantly.

The aim of this research is to empirically examine the sustainable aspects of airport energy management, in the context of Oslo Airport Gardermoen, Norway's principal air traffic hub. Environmental management forms an integral part of Oslo Airport Gardermoen's governance and management system. The airport's management system covers all regulatory requirements regarding internal control and is based on relevant requirements specified in international standards such as ISO 9001 Quality Management and 14001 Environmental Management Systems (EMS) (Avinor, 2021d). Oslo Airport Gardermoen Environmental Management System was certified as following the standard ISO 14001 standards in March 2014 (Vestvik-Lunde, 2014). Oslo Airport Gardermoen was selected as the single site in-depth exploratory case studied in this research. A further factor in selecting Oslo Airport Gardermoen as the case firm was the ready availability of the airport's annual environmental data for the period 2005 to 2020. A further key objective of the present study is to examine the airport's energy sources and the trends in the annual consumption of these energy sources, as well as examining the measures and technologies that have been implemented by Oslo Airport Gardermoen to mitigate the environmental impact of the energy consumed at the airport throughout the study period.

The remainder of the paper is organized as follows: Section 2 presents a review of the literature on sustainable airport energy management. The research method used to underpin the study is described in Section 3. The case study of Oslo Airport Gardermoen sustainable energy management is presented in Section 4. Section 5 presents the findings of the study.

\section{BACKGROUND}

As previously noted, airports are viewed as being extremely energy-intensive (Baxter et al., 2018a; Alba \& Manana, 2017; Sukumaran \& Sudhakar, 2017). Airport buildings are especially energy intensive (Kim et al., 2020; Yildiz et al., 2021). The significant energy consumption of an airport is due to the large buildings, which comprise the passenger terminals and non-passenger-related areas of the airport, that are equipped with heating and air-conditioning systems. Airports also have a high-power demand for lighting and electric equipment as well as the energy requirements from the many facilities located within the airport precinct (Cardona et al., 2006). Typically, an airport's heating, ventilation, and air conditioning (HVAC) system will represent the largest share of energy consumed in airport terminal buildings. It has been estimated that around $70 \%$ of the energy consumed in airport terminal buildings is used for heating, cooling, and air conditioning purposes. This energy consumption rate is higher in those countries that have a cold climate (Akyüz et al., 2017). Indeed, airport terminals have a high level of energy consumption for space heating in cold climate zones (Liu et al., 2021).

Airports need to provide electrical energy for the airfield aids that are used for air transport operations, for example, lighting and meteorological systems. Electrical energy is also required for airport buildings, aircraft hangers and other airport facilities (Kazda et al., 2015). Hence, energy management, which includes heating, ventilation, air conditioning, and lighting, is extremely important for airports (Graham, 2018). Furthermore, airports need to ensure that they have a guaranteed, appropriately priced, and secure energy supply. This because airports need to meet peak demand from their service partners and passengers thereby optimizing their operational capacity (Thomas \& Hooper, 2013).

The operation of more efficient heating and cooling systems and the performance of the building envelope can result in significant reductions in energy consumption. 
This can be achieved without compromising comfort conditions in the airport terminal buildings (Akyüz et al., 2018). To ensure that energy demand can be met when the needs arise, airports are increasingly focusing on energyconservation measures in the design (and operations) of terminal buildings and infrastructure (Thomas \& Hooper, 2013). Some airports have also developed and operate new power-generation systems that provide reliable and affordable sustainable energy whilst also lowering their energy costs (Budd \& Budd, 2013). Importantly, airports around the world are shifting toward the utilization of clean energy technologies together with the implementation of practices that reduce local emissions. This environmental-related strategy includes replacing fossil fuel-based with electricity-based operations at the airport (Sajed Sadati et al., 2018). Accordingly, airports are increasing their use of renewable energy sources. These include solar photovoltaic, concentrating solar power, wind power, oil and natural gas extraction, steamgenerated power production and electricity transmission (Barrett et al., 2014).

Energy consumed by airports can be broken down into the energy consumed by the airside activities undertaken at the airport as well as the energy consumed in the provision of the airport's landside area activities (Janić, 2011). The airside means the movement area at an airport, adjacent terrain and buildings/infrastructure, or portions, the access to which is restricted. Landside means those parts of an airport as well as the adjacent terrain and buildings or portions thereof that are not in the airside precinct (Rossi Dal Pozzo, 2015). In the airport's airside area, energy requirements include the fuel that is consumed by aircraft during the landing and take-off (LTO) cycles. Also, ground vehicles serving aircraft during the turnaround process at the apron/gate complex consume energy. In the airport landside area, the principal consumers of energy are the airport ground access systems/modes and passenger and air cargo terminals together with other administrative buildings serving the airport. In most cases, the primary energy sources are from non-renewable fossil fuels and to a smaller extent from renewable wind, water, and solar sources (Janić, 2011).

Electrical energy is normally sourced from different sources. The electrical energy is supplied directly to the airport through dedicated sub-stations. As noted earlier, this energy is primarily used for heating, cooling, lighting, and operating the airport's facilities, equipment, and other devices in the processes of servicing passengers and their baggage and air cargo consignments in passenger and cargo terminals, respectively. Electrical energy is also used for the provision of heating, cooling (air conditioning), and lighting other administrative buildings at airports (Janić, 2011).

\section{RESEARCH METHODOLOGY}

\subsection{Research Method}

This study used a qualitative longitudinal research design (Derrington, 2019; Hassett \& Paavilainen-Mäntymäki, 2013; Neale, 2018). Qualitative longitudinal research aims to expand and develop theories (Derrington, 2019). A case study enables the exploration of complex phenomena (Remenyi et al., 2010; Yin, 2018), and thus, the collection of rich, explanatory information that provides in-depth insights into the phenomenon being investigated (Ang, 2014). Case studies also enable the researcher(s) to connect with real world practice (McCutchen \& Meredith, 1993).

\subsection{Data Collection}

The qualitative data for this study was obtained from the annual Oslo Airport Gardermoen and Avinor AS environmental reports. Qualitative data was also gathered from the Avinor AS web sites. The study therefore used secondary data analysis to investigate the research problem.

A comprehensive examination of the leading airportrelated journals and airport industry magazines was also conducted. The study also included a search of the SCOPUS and Google Scholar databases.

The key words used in the database searches included "Oslo Airport Gardermoen total annual electricity consumption", "Oslo Airport Gardermoen total annual electricity consumption for airport specific installations", "Oslo Airport Gardermoen total annual purchased heating and colling energy", "Oslo Airport Gardermoen total annual electricity consumption for electrode boiler", "Oslo Airport Gardermoen total annual electricity consumption for compressors and pumps", "Oslo Airport Gardermoen total annual purchased heating and cooling energy", "Oslo Airport Gardermoen total annual heating oil consumption", "Oslo Airport Gardermoen total annual recovered energy", "Oslo Airport Gardermoen total annual heating and cooling energy", the annual jet fuel consumption at Oslo Airport Gardermoen", "Oslo Airport Gardermoen total heating oil/diesel consumption", "Oslo Airport Gardermoen total annual consumption of bio-heating oil", "Oslo Airport Gardermoen total annual consumption of bio-fuel for airport vehicles", "Oslo Airport Gardermoen total annual consumption of fuel for airport vehicles", and "Oslo Airport Gardermoen total annual consumption of fuels for firefighting drills", 
The study followed the three principles of data collection as recommended by Yin (2018), that is, the use of multiple sources of case evidence, creation of a database on the subject, and the establishment of a chain of evidence.

\subsection{Data Analysis}

The data collected for the case study was examined using document analysis, which is a research technique that has been extensively used in case study research. Document analysis focuses on the information and data from formal documents and company records (Oates, 2006; Ramon Gil-Garcia, 2012). Following the recommendations of Scott (2004, 2014) and Scott and Marshall (2009), the documents that were gathered for analysis in the study were examined for their authenticity, credibility, representativeness, and meaning.

The study's document analysis was conducted in six distinct stages. The first stage involved planning the types and required documentation and ascertaining their availability for the study. In the second phase, the data collection involved sourcing the documents from Oslo Airport Gardermoen and Avinor AS. This stage of the document analysis process also involved the development and implementation of a scheme for managing the documents collected for the study. The documents were carefully examined to assess their authenticity, credibility and to identify any potential bias in the third stage of the document analysis process. In the fourth stage, the content of the collected documents was carefully examined, and the key themes and issues were identified and recorded. The fifth stage involved the deliberation and refinement to identify any difficulties associated with the documents, reviewing sources, as well as exploring the documents content. In the sixth and concluding stage, the analysis of the data was finalized (O'Leary, 2004).

Following the recommendation of Yin (2018), all the gathered documents were downloaded and stored in a case study database. All the documents collected for the study were in English. Each document was carefully read, and key themes were coded and recorded in the case study (Baxter, 2021).

\section{RESULTS}

\subsection{A Brief Overview of Oslo Airport Gardermoen}

Oslo opened a new airport at Gardermoen, a redundant military airfield, in 1998. This new airport replaced Oslo Fornebu Airport (Feldman, 1998; Iatrou \& Williams, 2008). The capacity at Oslo Airport Fornebu was a restraining factor on traffic growth (Lian, 2010). The new airport related high-speed train and improved road system to the airport cost almost NOK 20 billion (\$USD 3 billion)
(Feldman, 1998). Oslo Airport Gardermoen (IATA Airport Code OSL) is Norway's major airport and air traffic hub. The airport is operated by Oslo Lufthavn AS, which was incorporated in 1992. Oslo Lufthavn AS is a subsidiary of Avinor AS (Bråthen \& Fuglum, 2016).

The airport is in the municipality of Ullensaker, approximately 47 kilometres north of Oslo (International Airport Review, 2010). Oslo Airport Gardermoen occupies an area of 13 square kilometres and has two runways 2,950 and 3,600 metres in length. The airport has a total of 72 gates (44 with aerobridges) and 7 gates (4 Code D and 3 Code F) located at the cargo terminals (Avinor, 2021a). A new passenger terminal, which opened in April 2017, has expanded the airport's annual capacity to 32 million passengers (Avinor, 2021e). The new passenger terminal was constructed west of the existing terminal building, and occupies an area of $117,000 \mathrm{~m}^{2}$. The new triangular-shaped pier termed 'Pier B' or 'North Pier' was built north of the existing terminal building and this pier has a floor area of 63,000m² (Airport Technology, 2017a).

The terminal building 265,000 square metres in size (Avinor, 2021a) and the airport's buildings are equipped with large glass walls. This requires large cooling demands in summer as well as large heating demands in during the winter period (Eggen \& Vangsnes, 2006). In addition, the expansion of the airport terminal building has also meant that there has been an increase in the heating and cooling requirements at the airport (Mæx Moe, 2018).

Figure 1 presents the growth in passenger traffic (domestic and international) at the airport from 2005 to 2020. The global financial crisis had an adverse impact on passenger travel with the annual number of enplaned passengers at Oslo Airport Gardermoen declining from 2008 to 2009. Since 2010, passenger traffic has shown a steady increase, however, it declined significantly in 2020 (Figure 1). In 2020, the COVID-19 pandemic caused a decline in economic activity around the world, and this resulted in disruptions in the supply and demand chain for the air travel market (Dube et al., 2021). In addition, because of the global coronavirus crisis, most countries placed restrictive measures in order to confine the pandemia (Maria Iacus et al., 2020), and these restrictions had an adverse impact on airline passenger demand. International passengers comprise the largest share on enplaned passengers at Oslo Airport Gardermoen. 


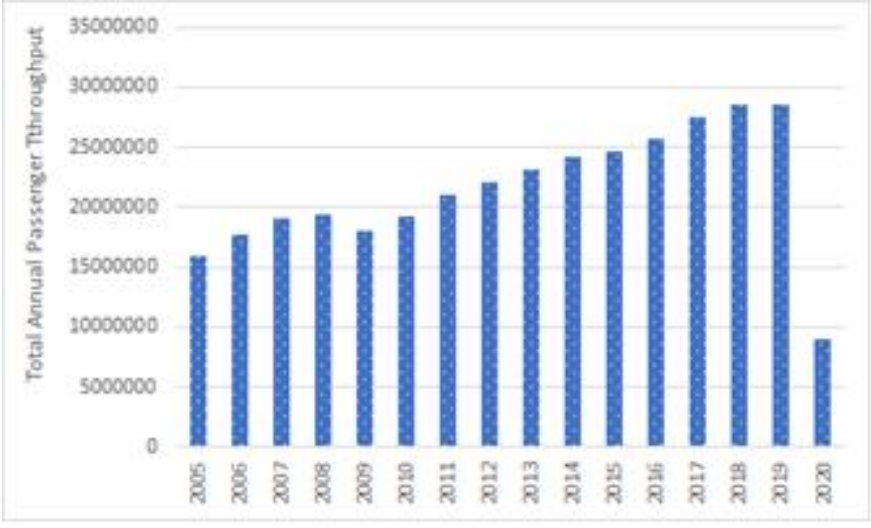

Fig.1: Total annual domestic and international enplaned passengers at Oslo Airport Gardermoen: 2005-2010. Note: From 2013 passengers comprise scheduled and charter and includes infants. Source: Data derived from Avinor AS (2021b).

Figure 2 shows the total annual domestic and international aircraft movements at the airport from 2005 to 2020. Like the annual enplaned passenger traffic, there was a decline in aircraft movements in 2009, however, since 2010, the annual aircraft movements showed a steady annual growth rate before declining significantly in 2020, with the decrease in aircraft movements reflecting the lower level of airline operations as a result of the Covid 19 pandemic.

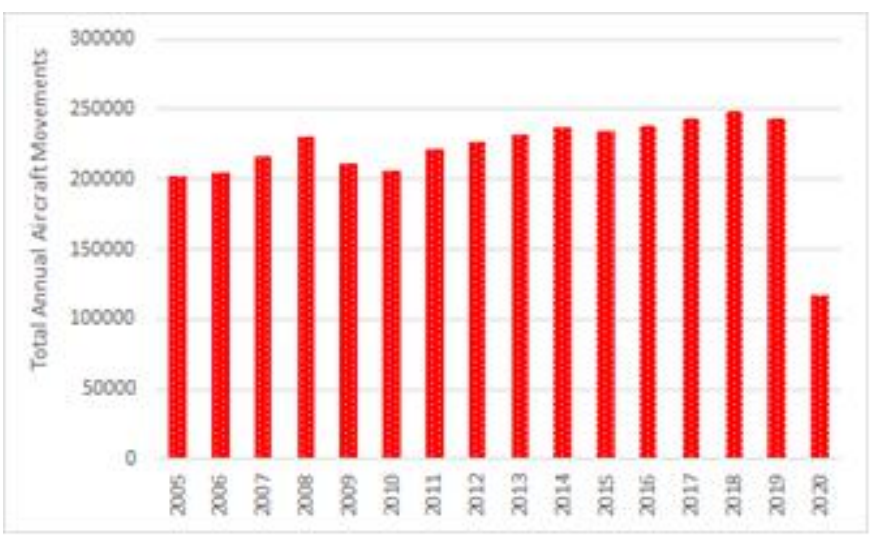

Fig.2: Total annual aircraft movements (domestic and international) at Oslo Airport Gardermoen: 2005-2010.

Source: Data derived from Avinor AS (2021b).

\subsection{Avinor AS Environmental and Corporate Social Responsibility Policy}

Avinor AS is a fully owned state limited company under the Norwegian Ministry of Transport and Communications. Avinor AS is responsible for the management and operations of 44 state-owned airports located throughout Norway (The Avinor Group, 2021). Oslo Airport Gardermoen is managed and operated by Avinor AS. Avinor AS has defined and implemented a comprehensive policy which describes the general principles for environmental and social responsibility in the company. The purpose of this policy is to improve Avinor's own environmental performance, ensure the company is a driving force in the environmental work in the aviation industry, and for the company to be a leader in the work on corporate social responsibility in the Norwegian aviation industry (Oslo Lufthavn AS, 2021, p. 4).

The environmental principles prescribed in the policy are as follows:

- Avinor works to constantly improve its environmental performance and the company actively works to reduce the impact of the business on the environment.

- Avinor is required to comply with all regulatory requirements and its own requirements, and the company's environmental management must be in accordance with ISO14001, to ensure a systematic approach to coordination and followup of environmental work.

- Avinor must ensure there is a high degree of environmental awareness and expertise throughout the entire group.

- Employees and partners at the airport must be aware of the Avinor Group's significant environmental aspects.

- Avinor must emphasize and integrate environmental

- Considerations early in the planning and implementation of projects and when purchasing products and materials. Furthermore, the business

- Avinor must place a strong emphasis on the environment in expansion projects.

- Avinor aims to maintain open, constructive, and proactive communication with its partners, local communities, authorities, aviation organizations and other stakeholders in order to reduce environmental impact of its operations.

- Avinor seeks solutions to environmental challenges through cooperation with research and development communities, authorities, and other organizations both at a national and international level (Oslo Lufthavn AS, 2021, p. 3).

Environmental management is an integral part of Avinor's management system. As previously noted, in March 2014, Oslo Airport Gardermoen was certified according to ENNS ISO14001: 2004. The airport is now a part of the common Avinor certificate, which is also in accordance 
with ISO standard 14001:2015 Environmental Management System (Oslo Lufthavn AS, 2021). ISO 14001 is a worldwide meta-standard for implementing Environmental Management Systems (EMS) (Dentch, 2016; Grover \& Grover, 2017; Heras-Saizarbitoria et al., 2011).

The recognition of being a "green airport" is an important strategic objective for Oslo Airport Gardermoen (Oslo Airport, 2020). A "green airport" is an airport which has a minimal impact on the environment and is one that endeavors to become a carbon neutral facility in terms of carbon emissions, with the aim to ultimately produce zero greenhouse gas emissions (González-Ruiz et al., 2017). The concept underpinning a "green airport" is for the airport to create a centre of sustainable practices (Sumathi et al., 2018). Oslo Airport Gardermoen "Green Airport" strategic objective involves an improvement in the performance and understanding the mechanisms that influence the airport's environmental reputation. In addition, the airport envisages that through the change of infrastructure and processes, it will reduce the airport's environmental impact through continuous improvement, innovative solutions and through the focus on the most effective measures. Also, the airport envisages that open and active communication will further strengthen the airport's environmental reputation (Oslo Lufthavn AS, 2020).

It is important to note that Oslo Airport Gardermoen Energy central has a high capacity and consequently is subject to regulations regarding greenhouse gas emission (GHG) allowance trading. Oslo Airport has been granted a quota-regulated emission permit from the Norwegian Environment Agency for emissions which are subject to quotas and are compensated annually for carbon dioxide (CO2) emissions in the EU's quota system (Oslo Lufthavn AS, 2019).

Oslo Airport has been working extremely proactively on energy efficiency measures in recent years, and the airport's percentage of renewable energy now exceeds 90 percent annually. Furthermore, there has been considerable expansion at Oslo Airport Gardermoen in recent times, and energy consumption is predicted to increase in the future, even when energy efficiency measures are implemented. These energy saving initiatives are examined in the latter section of the paper. Oslo Airport Gardermoen aim was to use only renewable energy by 2020. This goal was anticipated to be achieved through the selection and implementation of energy efficient solutions when modernizing and replacing equipment as well as changing from fossil energy to bioenergy (Oslo Lufthavn AS, 2019).

\subsection{Oslo Airport Gardermoen Energy System}

The energy system that supplies Oslo Airport's buildings, tenants, and road heating systems with energy for heating and cooling is comprised of a remote heating plant, a remote cooling plant, a snow cooling plant, a groundwater plant as well as a wastewater heat exchanger system (sewage) (Oslo Airport, 2020, p.11). Heating and cooling energy is distributed through a district heating and cooling network to the airport's tenants, the Police, the Flyporten Business Centre, the airport terminal, the railway station, the Scandinavian Airlines (SAS) operations building, the SAS Radisson Hotel and the airport's own buildings (Oslo Lufthavn AS, 2009)

One of the largest groundwater aquifers in Norway is located underneath the airport (Birhanu et al., 2015; French \& Binley, 2004; Wejden \& Øvstedal, 2006). This aquifer is used for both heating and cooling of Oslo Gardermoen Airport. During summer, ground water is pumped from cold wells and is then used for cooling before it is returned to the warm wells. In winter, this process is reversed, as ground water from the warm wells is used as heat source for the heat pump. The district cooling water is pre-cooled by the ground water, and post cooled by the combined heat pump/refrigeration plant. The airport's base heat load is covered by the heat pump. Additional heat is supplied from a heat energy central with biofuels as well as oil heated and electrically heated boilers. (Eggen \& Vangsnes, 2006). In 2018, the drilling of two deep water geothermal wells 1,500 metres in depth was completed. These wells are used to supply the ground heating system located in the airport's aircraft engine test area. By keeping snow and ice free all year round, at the time of the present study, the wells were each supplying between 60-100 KWh of heat and did not require the use of a heat pump (Oslo Lufthavn AS, 2019).

Oslo has a continental type of climate, with the city typically experiencing cold winters (Climates to Travel, 2012; Larssen et al., 1994). During the winter period, the airport's remote heating plant ensures that the buildings located within the airport precinct are kept sufficiently warm. This remote heating plant uses water-based heating. In addition, Oslo Airport also has its own remote heating plant which uses remote heating from Statkraft Varme AS. Woodchips are the source of the heating provided by Statkraft Varme AS (Oslo Lufthavn AS, 2020).

During summer, Oslo Airport Gardermoen remote cooling plant ensures that airport's buildings are kept sufficiently cool. At Oslo Airport Gardermoen, snow is stored during the winter season in a large basin. During summer, the melting water is used for cooling the airport's terminal on those days that require extra cooling needs (Oslo Lufthavn 
AS, 2020). At Oslo Airport Gardermoen, the snow cooling infrastructure and system stores snow and ice from the runway in the winter and, as previously noted, uses the water from the melting snow for cooling in the summer. This is achieved through the exploitation of the characteristics of snow's thermal energy potential. At Oslo Airport Gardermoen the snow is stored in the ground and is thermally insulated with wood chips (Mæx Moe, 2018). At Oslo Airport Gardermoen, the gathered snow is divided into two categories, pure and impure, that is, whether it contains or does not contain de-icing chemicals from runway and taxiway de-icing. The pure snow is collected in a large snow stockpile shaped like a basin. When the basin is full it is covered with sawdust. Sawdust insulates very effectively, allowing the airport to utilize the cold temperatures in the snow and ice. The coldness of the meltwater is recovered in a heat exchanger and transferred to the airport's central cooling plant. The meltwater is subsequently returned to the stockpile to repeat the heat exchange with the snow and ice in the snow stockpile. This is followed by a new cycle of transmission of cold energy to central cooling systems. The energy in the snow and the cold meltwater is subsequently used to cool the airport's North Pier on hot days (Avinor, 2021f).

Oslo Airport Gardermoen also uses grey water and the ground water under the airport for its heating (Airport Technology, 2017b). Grey water is water that is slightly contaminated by human activities and may possibly be reused following suitable treatment (Liu et al., 2010). The airport's terminal building is also designed as a "passive house" which is a German concept; this means the terminal building is designed so it requires less energy. Furthermore, the airport's terminal building has good insulation throughout the whole building; the windows minimize energy loss, and the terminal building has a solar screen to keep the sun away during sunny periods (Airport Technology, 2017b).

In addition, the airport's groundwater plant provides an interim storage facility for surplus energy. Large heat pumps, groundwater wells, heat exchangers to the airport's sewerage system (from the municipality of Ullensaker's treatment plant) and surface water represent the principal contribution to Oslo Airport's high percentage of renewable energy. The fossil fuel boilers have been assigned a low priority. These boilers are only used for test operations and during the times that Statkraft Varme and the electric boiler are unable to supply sufficient energy (Oslo Lufthavn AS, 2020).

Oslo Airport Gardermoen's passenger terminal building was also the first airport building to be awarded an Excellent BREEAM rating (Building Research
Establishment Environmental Assessment Method) (Business Traveller, 2017; Ros, 2017).

\subsection{The Annual Electricity Consumption at Oslo Airport Gardermoen}

Prior to examining the trends in Oslo Airport Gardermoen, it is important to note that in Norway hydropower accounts for the most of Norwegian power supplies. One unique characteristic of the Norwegian hydropower system is its high storage capacity. Norway has half of Europe's reservoir storage capacity. Moreover, more than $75 \%$ of Norwegian production capacity is flexible. Production can thus be rapidly increased and decreased as needed, at low cost (Norwegian Ministry of Petroleum and Energy, 2021). Hydroelectric power (hydro) is regarded as a renewable energy source because it relies on the Earth's natural water cycle's kinetic energy to generate electricity (McEntee, 2021). Hydropower is a climate-friendly energy source, as it generates power without producing harmful air pollution or toxic by-products (National Hydropower Association, 2021). In addition, renewable power plants are typically sited in Norway where there is access to resources. At the start of 2021, there were 53 wind farms located in Norway. This corresponds to approximately 13.1 terra watts (TW) in a normal year. In addition, during the beginning of 2021, the total installed capacity for solar power throughout was 160 megawatts (MW) (Norwegian Ministry of Petroleum and Energy, 2021). Because it is renewable, wind power generates almost no emissions of greenhouses gases (GHGs) and other pollutants (Ledec et al., 2011; Wang \& Prinn, 2010; Warren et al., 2005). Solar energy systems/power plants do not produce air pollution or greenhouse gases. Thus, the use of solar energy can have a positive, indirect impact on the environment when solar energy replaces or reduces the use of other energy sources that have larger environmental effects (United States Energy Information Agency, 2020).

The total annual electricity consumption at Oslo Airport Gardermoen and the year-on-year change (\%) for the period 2005 to 2020 is presented in Figure 3. The highest single annual electricity consumption was recorded in 2018, when the airport consumed a total of $120 \mathrm{GWh}$ of electricity (Figure 3). As can be observed in Figure 3, the airport's annual electricity consumption has largely displayed an upward trend. This is demonstrated by the year-on-year percentage change line graph, which is more positive than negative, that is, more values are above the line than below. The increase in Oslo Airport Gardermoen total annual electricity consumption throughout the study period has been due to a range of factors. During 2005, 2006, and 2007 there was an increase in electricity usage in the airport terminal building, the eastern area of the airport as well as in external areas. In addition, there was 
also an increase in the airport's runway electricity requirements (Oslo Lufthavn AS, 2008). Oslo Airport Gardermoen opened a new multi-level car park in 2008. The electricity consumption for this new facility was estimated to be around $2.8 \mathrm{GWh}$. However, because of the reduced energy demands in the airport's other facilities, there was only a small $(+0.13 \%)$ increase in electricity consumption compared to the 2007 levels (Oslo Lufthavn AS, 2009). One of the key factors influencing the increase in electricity consumption in 2009 was the completion of the airport's terminal building eastern extension as well as the apron extension in the western area of the airport (Oslo Lufthavn AS, 2010). An airport apron is the defined area of land located within the airport precinct that accommodates, the parking, loading/unloading, refueling and maintenance activities of an aircraft (Budd \& Ison, 2017). Also, there was an increase in the electricity consumption of a new indoor car parking facility (this facility became operational in the fall of 2008) (Oslo Lufthavn AS, 2010). In 2010, the total energy consumption of the airport's Energy Centre increased due to higher energy requirements. The opening of the new hotel Park Inn in 2010 also contributed to the higher electricity consumption recorded by the airport in 2010 (Oslo Lufthavn AS, 2011).

A key factor that influenced Oslo Airport Gardermoen's higher electricity consumption in 2011 was the major building projects at the airport, with the concomitant worker accommodation, and the offices and service facilities that were in the north area of the airport terminal building together with the building site facilities associated with the work on the southern terminal pier. In addition, the extension of technical installations and commercial areas of the airport terminal, and a $10.8 \%$ growth in passenger volumes contributed to the higher energy requirements, some of which were offset by various energy saving initiatives (as discussed below) (Oslo Lufthavn AS, 2012). In 2012, electrical consumption for electricityspecific installations increased by $5.7 \mathrm{GWh}$. The factors that contributed to this increase in electricity consumption were the infrastructure expansions, such as, the airport's runway system at the northern end, South Pier, and restaurants in the West Pier, together with increased building activities and associated barrack rigs. Another factor was the growth in passenger volumes at the airport. In addition, the consumption of thermal energy production, district heating and electrical energy reflected the weather conditions in 2012 and increased by approximately eight per cent as compared with 2011 (Figure 3) (Oslo Lufthavn AS, 2013). In 2013, the consumption of thermal energy production, district heating and electricity reflected the addition of new airport buildings the prevailing weather conditions (Oslo Lufthavn AS, 2014).

Figure 3 also shows that there were three years in the study period where the airport's total annual electricity consumption decreased on a year-on-year basis. These decreases were recorded in 2007 (-0.93\%), 2019 (-2.5\%), and $2020(-15.38 \%)$ and reflected lower energy requirements during these years.

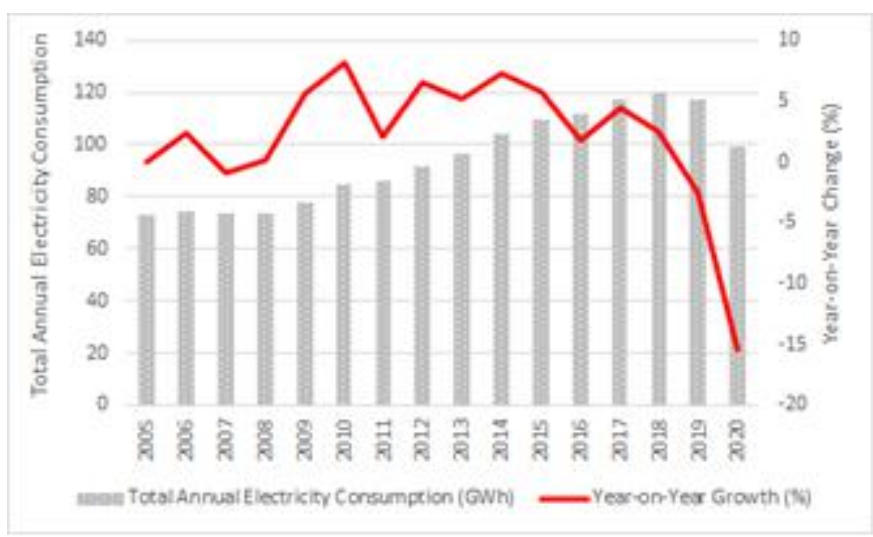

Fig.3: The annual electricity consumption at Oslo Airport Gardermoen and year-on-year change (\%): 2005-2020. Source: Data derived from Oslo Airport AS (2008, 2011, 2016, 2021).

Through the airport's own high-voltage grid, Oslo Airport Gardermoen supplies electricity to its tenants, which include the police, the Flyporten Business Centre, the airport terminal, the airport's railway station and the airport's own buildings and installations. This energy is referred to as electric specific installations (Oslo Lufthavn AS, 2009). Oslo Airport Gardermoen's total annual electricity consumption for airport-specific installations (KWh) and the year-on-year change (\%) for the period 2005 to 2020 is depicted in Figure 4. As can be observed in Figure 4, the airport's annual electricity consumption for airport-specific installations has largely displayed an upward trend. This is demonstrated by the year-on-year percentage change line graph, which is more positive than negative, that is, more values are above the line than below. As previously noted, the increases in airport-related infrastructure have resulted in an increased energy consumption. Figure 4 shows that there was a marked decrease in this metric, when electricity for airport specific installations decreased by $15.38 \%$ in 2020 on the 2019 levels. During the study period, there were two years where this metric declined. These decreases occurred in $2007(-0.93 \%)$ and in $2020(-15.38 \%)$. 


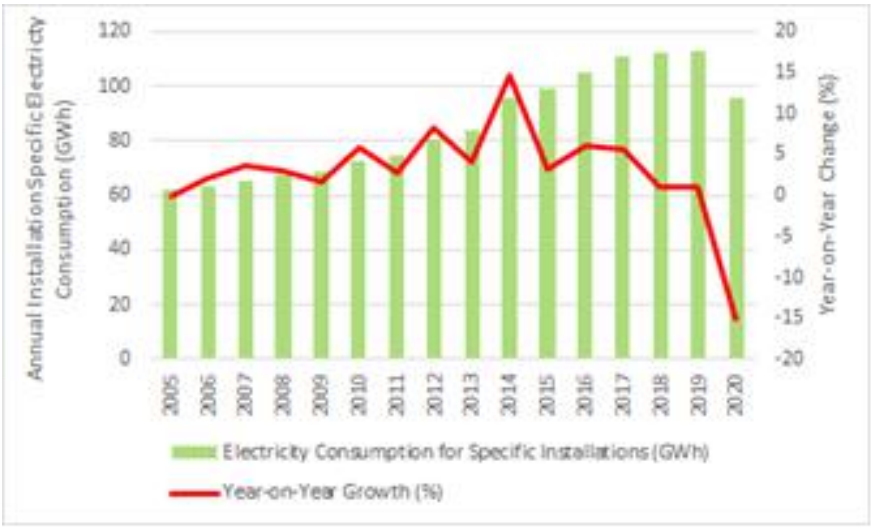

Fig.4: The annual electricity consumption for airport specific installations at Oslo Airport Gardermoen and year-on-year change (\%): 2005-2020. Source: Data derived from Oslo Airport AS (2008, 2011, 2016, 2021).

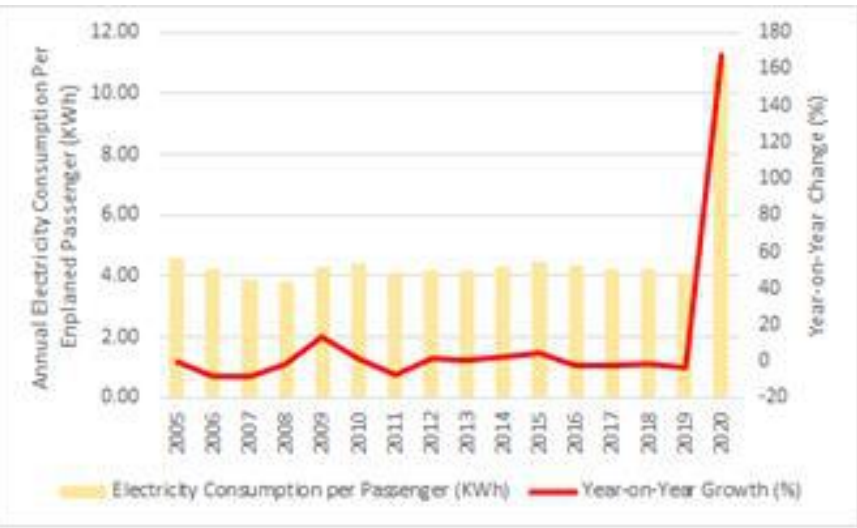

Fig.5: The annual electricity consumption per enplaned passenger at Oslo Airport Gardermoen and year-on-year change (\%): 2005-2020. Source: Data derived from Oslo Airport AS (2008, 2011, 2016, 2021).

Airport energy efficiency can also be measured by energy consumed per aircraft movement (Janić, 2017). Oslo Airport Gardermoen's total annual electricity consumption per aircraft movement (KWh) and the year-on-year change (\%) for the period 2005 to 2020 is depicted in Figure 6. As can be seen in Figure 6, the total annual electricity per aircraft movement at Oslo Airport Gardermoen has exhibited an upward trend, increasing from 305.65 KWh per aircraft movement in 2005 to a high of $846.15 \mathrm{KWh}$ per aircraft movement in 2020. Figure 6 shows that there were three pronounced annual increases in the electricity per aircraft. These occurred in 2010 when the annual electricity per aircraft movement increased by $8.24 \%$ on the previous year's level and in 2014, when there was increase of $11.61 \%$ on the 2013 levels, and again in 2020, when the electricity consumption per aircraft movement increased by $76.46 \%$ on the 2019 levels. It is important to note that there was a $52.04 \%$ decrease in the number of aircraft movements in 2020, whilst the total annual electricity consumption in 2020 decreased by $15.38 \%$ on the 2019 level. Thus, the large increase in electricity per aircraft movement is due to the lower number of aircraft movements in 2020. Throughout the study period, there were three years when the total annual electricity consumption per aircraft decreased on a year-on-year basis. These decreases were recorded in 2008 (-3.43\%), $2011(-4.07 \%)$, and 2018 (-1.53\%), respectively (Figure 6). It is important to note that throughout the study period, the size of commercial aircraft has increased. The Airbus A380 entered commercial service with Singapore Airlines in October 2007 (Jackson, 2021; Simons, 2014). The Boeing 747-8 Intercontinental first commercial flight took place on 1 June 2012 (Asian Aviation, 2012). The Boeing 787-8 first entered commercial service in 2011. The Airbus A350-900XWB first commercial flight was operated by 
Qatar Airways in 2014 (Aircraft Commerce, 2015). Singapore Airlines took delivery of the first Boeing 787-10 on March 14th, 2018 (Boon, 2020). The Boeing 787-8 is around 20 seats larger than the Boeing 767-300ER, whilst the Boeing 787-9 has about 20 seats more capacity than the A330-200 (Aircraft Commerce, 2016).

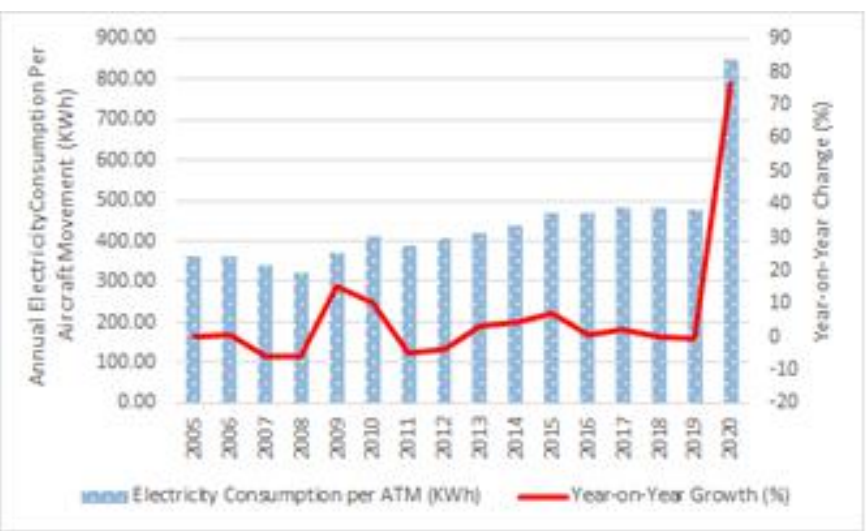

Fig.6: The annual electricity consumption per aircraft movement at Oslo Airport Gardermoen and year-on-year change (\%): 2005-2020. Source: Data derived from Oslo

Airport AS (2008, 2011, 2016, 2021).

\subsection{The Annual Consumed Energy for Heating and Cooling at Oslo Airport Gardermoen}

Like other airports around the world, Oslo Airport Gardermoen purchases both heating and cooling energy. The total annual purchased heating and cooling energy consumption and the year-on-year change $(\%)$ for the period 2005 to 2020 is depicted in Figure 7. As can be observed in Figure 7, the annual purchased heating and cooling energy consumption at the airport increased from 41.3 GWh in 2005 to $65 \mathrm{GWh}$ in 2020. The highest annual consumption of purchased heating and cooling energy occurred in 2018, when the total annual consumption was $71 \mathrm{GWh}$. The largest single annual increase in the airport's purchased heating and cooling energy was recorded in 2016 , when this energy source increased by $24.44 \%$ on the 2015 levels. Figure 7 also shows that the airport was able to decrease its consumption of heating and cooling energy in six years of the study period. These decreases reflected lower consumption levels and were recorded in 2007 ($3.87 \%), 2008(-3.13 \%), 2011(-12.9 \%), 2014(-1.47 \%)$, $2015(-5.46 \%)$, and in $2019(-9.85 \%)$, respectively (Figure $7)$. The 2019 result is particularly favorable given the larger heating and cooling requirement of the airport's expanded terminal building, which as noted earlier, became operational in 2017.

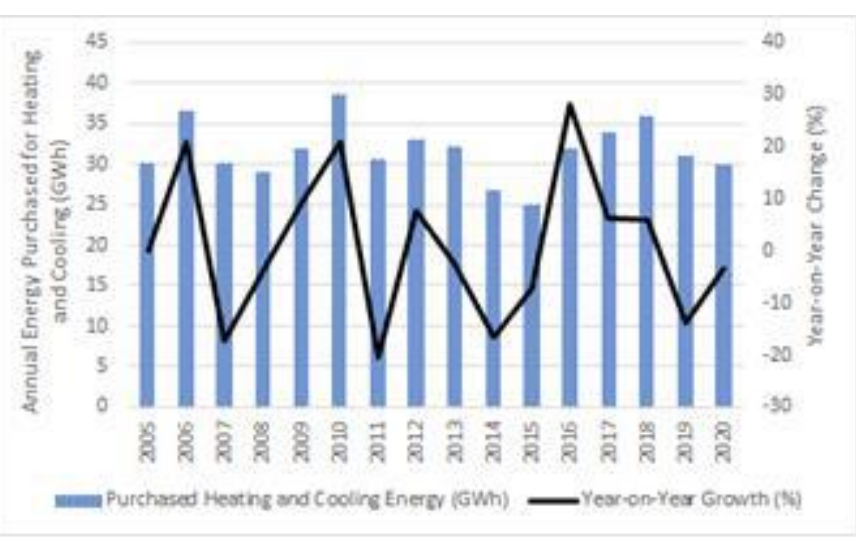

Fig.7: The annual purchased heating and cooling energy by Oslo Airport Gardermoen and year-on-year change (\%): 2005-2020. Source: Data derived from Oslo Airport $A S$ (2008, 2011, 2016, 2021).

\subsection{The Annual Electricity Consumption for Compressors and Pumps at Oslo Airport Gardermoen}

The total annual electricity consumption for the compressors and pumps used at Oslo Airport Gardermoen and the associated year-on-year change (\%) from 2005 to 2020 are depicted in Figure 8. As can be observed in Figure 8, the annual electricity consumption for the compressors and pumps used at the airport has gone through discrete stages. In stage 1, that is, from 2005-2009, the annual energy consumption remained relatively stable at around 6.24 GWh per year. From 2010 to 2013, stage 2, there was a pronounced increase in this energy source, with the highest single annual consumption was recorded in 2010, when the total annual consumption increased by $315 \%$ on the 2009 levels. In the third stage, from 2014 to 2020, the consumption remained relatively consistent, averaging between $9 \mathrm{GWh}$ and $11 \mathrm{GWh}$ per annum (Figure 8).

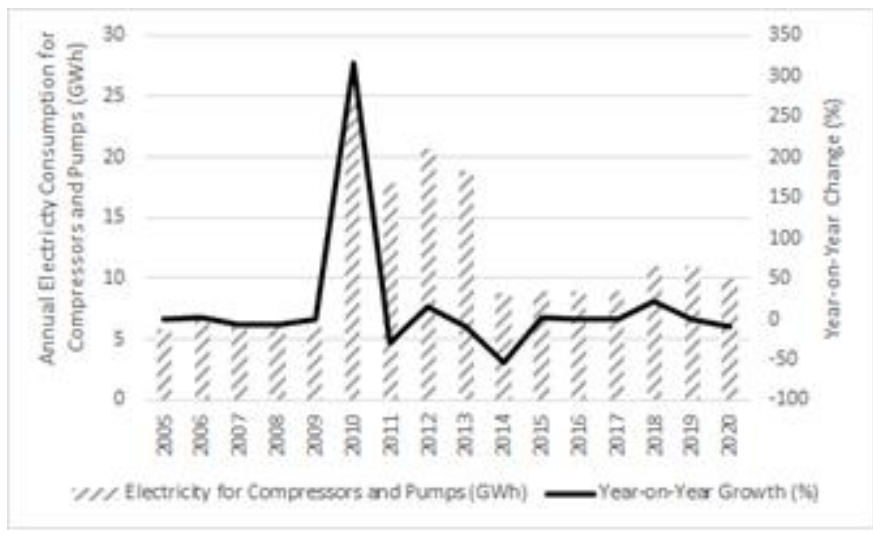

Fig.8: The annual consumption of electricity for compressors and pumps at Oslo Airport Gardermoen and year-on-year change (\%): 2005-2020. Source: Data derived from Oslo Airport AS (2008, 2011, 2016, 2021). 


\subsection{The Annual Electricity Consumption for Electrode Boiler at Oslo Airport Gardermoen}

The total annual electricity consumption for the Oslo Airport Gardermoen electrode boiler and the year-on-year change (\%) from 2005 to 2020 are depicted in Figure 9. As can be observed in Figure 9, the annual electricity consumption for the airport's electrode boiler oscillated throughout the study period. Figure 9 shows that there was a pronounced spike in this metric in 2009 , when the annual electricity consumption increased by $375 \%$ on the 2008 level. In 2010, the total annual electricity consumption rose by $50 \%$ on the 2009 level (Figure 9). There was a further spike recorded in 2014, when the boiler annual electricity consumption increased by $68.75 \%$ on the 2013 level (Figure 9). Figure 9 also shows that throughout the study period, there were ten years where the year-on-year total annual electricity consumption decreased on a yearon-year basis. The largest single annual decrease was recorded in 2007, when the boiler's annual electricity consumption decreased by $53.33 \%$ on the 2006 level. Figure 9 also shows that there were two significant decreases recorded in $2019(-50 \%)$ and 2020 (-25\%), respectively.

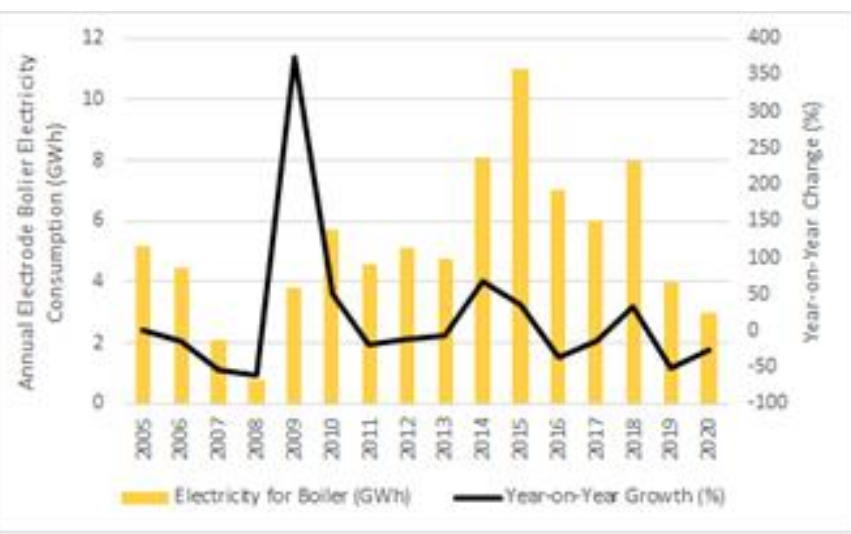

Fig.9: The annual consumption of electricity for electrode boiler at Oslo Airport Gardermoen and year-on-year change (\%): 2005-2020. Source: Data derived from Oslo Airport AS (2008, 2011, 2016, 2021).

\subsection{The Annual Consumption of Hafslund Fjernvarme AS Supplied District Heating Energy at Oslo Airport Gardermoen}

From 2005 to 2014, Oslo Airport Gardermoen purchased district heating from Hafslund Fjernvarme AS. Hafslund Fjernvarme AS. used biofuels and oil in the production of district heating energy. In 2005, Hafslund Fjernvarme AS. installed an additional boiler, whereupon the airport signed an additional agreement for deliveries of district heating energy as this was a key part of the airport's heating and cooling system (Oslo Lufthavn AS, 2008). Figure 10 presents the total district heating energy purchased from Hafslund Fjernvarme AS and the year-on-year change (\%) for the period 2005 to 2014. As can be observed in Figure 10 , the annual consumption of district heating energy fluctuated throughout this period and reflected the airport's heating and cooling requirements. In 2006, there was a pronounced spike when this energy source consumption increased by $66.17 \%$ on the 2005 levels. The second most significant annual increase was recorded in 2010 $(+17.45 \%)$. Figure 9 also shows that there were four years when the annual consumption of purchased district heating energy declined on a year-on-year basis. These decreases were recorded in 2007 (-22.12\%), 2011 (-28.51\%), 2013 ($8.69 \%$ ), and in $2014(-53.43 \%)$, respectively (Figure 10). In 2007 , the number of degree days was $11 \%$ below the norm experienced at Oslo Airport Gardermoen, which resulted in a lower demand for thermal energy (Oslo Lufthavn AS, 2008).

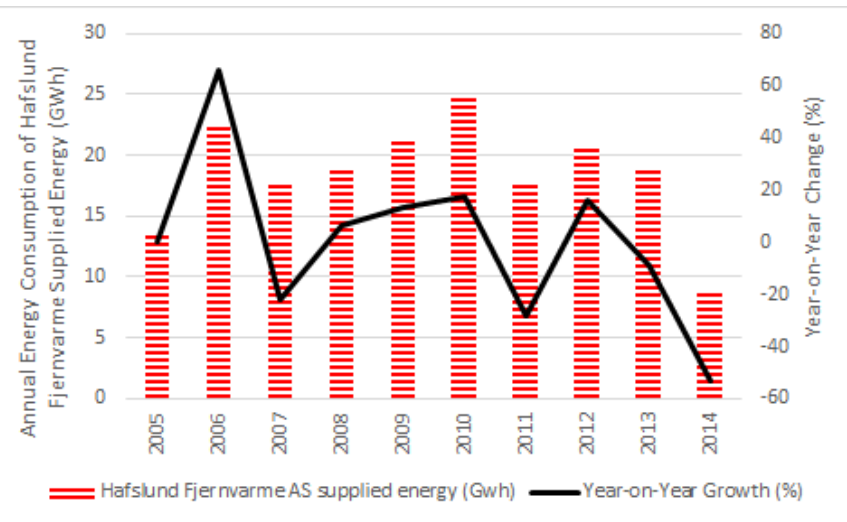

Fig. 10: The annual purchased district heating from Hafslund Fjernvarme by Oslo Airport Gardermoen and year-on-year change (\%): 2005-2014. Source: Data derived from Oslo Airport AS (2008, 2011, 2016).

4.8 The Annual Consumption of Statkraft Varme AS Supplied District Heating energy at Oslo Airport Gardermoen

From 2015 to 2020, Oslo Airport Gardermoen purchased remote district heating from Statkraft Varme AS. Statkraft Varme AS supplied district heating is sourced from woodchips (Oslo Lufthavn AS, 2020). The total annual purchased district heating energy from Statkraft Varme AS and the year-on-year change for the period 2005 to 2020 is presented in Figure 11. As can be observed in Figure 11, the annual consumption of district heating sourced from Statkraft Varme AS fluctuated over the study period due to differing heating requirements at the airport. Figure 11 shows that the highest annual consumption of district supplied heating from Statkraft Varme AS was recorded in 
2019 (17 GWh), whilst the lowest level of consumption occurred in 2015 (5 GWh). The highest single annual increase in this district heating occurred in 2016, when the annual consumption increased by $200 \%$ on the 2015 levels. Figure 11 shows that there were two years in the study period where the annual district heating consumption decreased on a year-on-year basis. The decreases were recorded in $2018(-6.25 \%)$ and in $2020(-5.88 \%)$, respectively, and reflected the lower heating requirements in these two years (Figure 11).

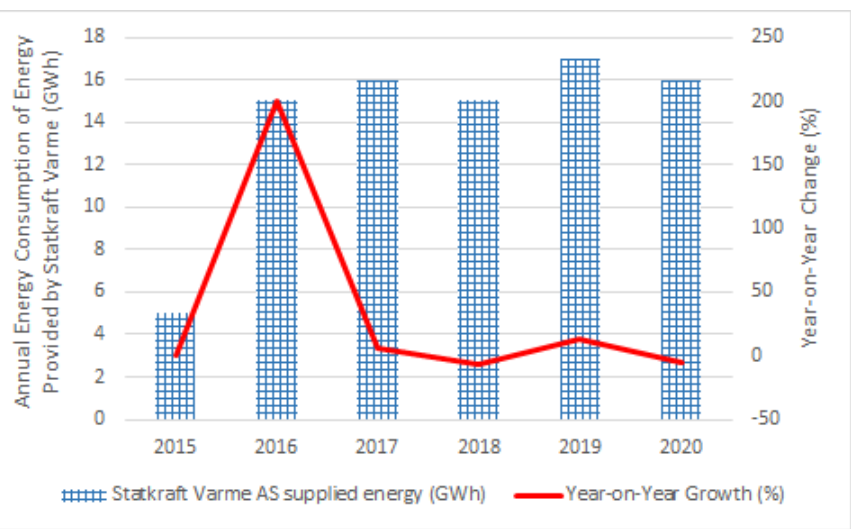

Fig. 11: The annual purchased district heating from Statkraft Varme AS by Oslo Airport Gardermoen and yearon-year change (\%): 2015-2020. Source: Data derived from Oslo Airport AS (2016, 2021).

\subsection{The Annual Heating Oil Consumption for Energy Central at Oslo Airport Gardermoen}

The total annual heating oil consumption for Oslo Airport Gardermoen's Energy Central and the year-on-year change (\%) from 2005 to 2020 is depicted in Figure 12. As can be observed in Figure 12, the airport's annual heating oil consumption for Energy Central has principally displayed a downward trend. This is demonstrated by the year-onyear percentage change line graph, which is more negative than positive, that is, more values are below the line than above. However, as can be observed in Figure 12, there were four years during the study period where there were pronounced spikes in the annual consumption of heating oil for the airport's Energy Central. These spikes occurred in $2007(+53.84 \%), 2010(+66.66 \%), 2014(+200 \%)$, and $2017(+300 \%)$ with these increases being the result of greater heating requirements in these years. Figure 12 also shows that there were five years during the study period, where the airport's annual consumption of heating oil for its Energy Central declined quite significantly on a yearon-year basis. These decreases were recorded in 2006 ($52.72 \%), 2009$ (-74.28\%), 2014 (-71.42\%), 2018 (-50\%), and $2019(-50 \%)$ (Figure 12). In recent times, heating oil has only been used at the airport to a limited extent. The reduction in the use of heating oil is a result of the airport's greenhouse gas (GHG) reduction measures. As noted below, the airport has been transitioning to biofuel oil to further reduce consumption. In addition, the oil boilers that are in the airport's thermal plant are only used for emergencies and consumption of fuel oil is limited to test runs (Avinor AS, 2021c).

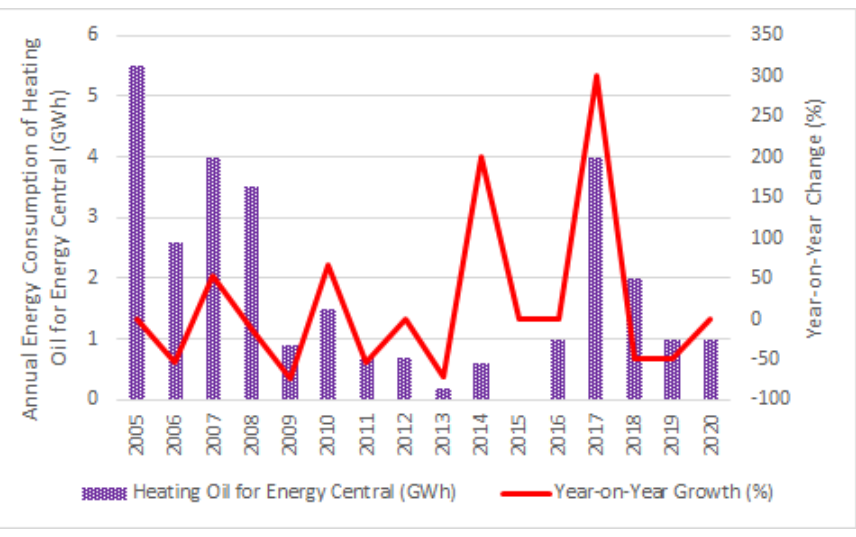

Fig.12: The annual heating oil consumption for Energy Central at Oslo Airport Gardermoen and year-on-year change (\%): 2005-2020. Source: Data derived from Oslo Airport AS (2008, 2011, 2016, 2021).

\subsection{The total annual recovered energy at Oslo Airport Gardermoen}

The total annual recovered energy at Oslo Airport Gardermoen and the year-on-year change (\%) for the period 2005 to 2020 is shown in Figure 13. Energy recovery is defined as the process of extracting useful energy from waste, for example, heat from the incineration of wastes (Allaby \& Park, 2007). Figure 13 shows that the total annual recovered energy increased from $11.1 \mathrm{GWh}$ in 2005 to a high of $35 \mathrm{GWh}$ in 2020 . Figure 13 also shows that there has been a general upward trend with pronounced spikes in $2007+47.95 \%, 2014+28.57 \%$, and in $2017+29.16 \%$, respectively (Figure 13). Throughout the study period, the total annual recovery at the airport decreased on a year-on-year basis in six years, that is, 2006, 2008, 2009, 2010, 2015 and 2019, respectively. the largest single annual decrease in the annual recovered energy occurred in 2006, when the total annual recovered energy decreased by $11.71 \%$ on the 2005 level (Figure 13). 


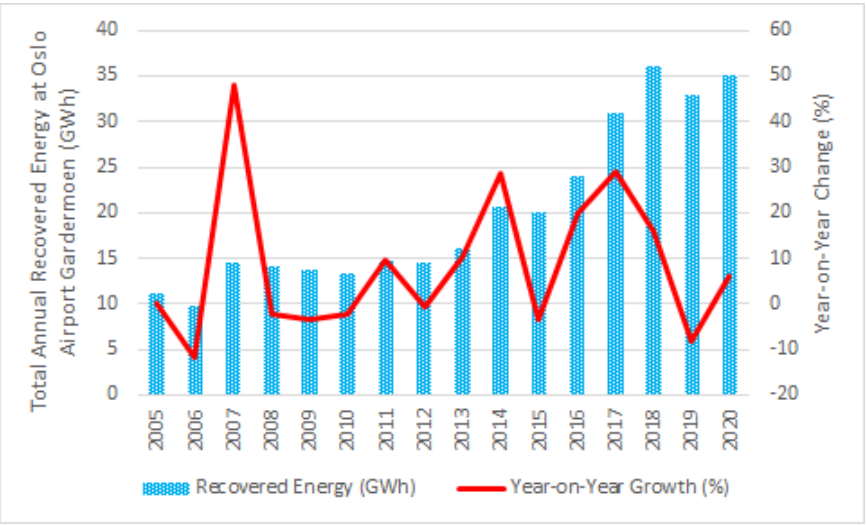

Fig.13: The annual recovered energy at Oslo Airport Gardermoen and year-on-year change (\%): 2005-2020. Source: Data derived from Oslo Airport AS (2008, 2011, 2016, 2021).

From an environmental perspective, energy recovery enables firms to reduce their greenhouse gas emissions as well as minimizing waste to landfill. Indeed, energy recovery enables the generation of energy more sustainably (Energy Australia, 2021). As material recycling, energy recovery has a concomitant linkage with the prevention and minimization of waste. Energy recovery is one of the two primary means of valorizing the waste that does occur and hence reduces its environmental and economic impacts. When taking together, material recycling and energy recovery offer a firm alternative and complementary ways of gaining the greatest sustainable benefit from natural resources and their wastes, thus reducing the consumption of virgin resources (Shulman, 2019).

\subsection{Non-renewable Energy Resources Usage at Oslo Airport Gardermoen}

4.11.1 Annual Bio-heating Oil Consumption at Oslo Airport Gardermoen

The total annual bio-heating oil consumption at Oslo Airport Gardermoen and the year-on-year change (\%) from 2014 to 2020 is depicted in Figure 14. Bio heating oil is a blend of biodiesel fuel that is blended with traditional heating oil (Apgar Oil, 2021). Figure 14 shows that there has been an upward trend in the airport's consumption of bio-heating oil. The overall increase in bio-heating oil consumption at the airport is demonstrated by the year-onyear percentage change line graph, which is more positive than negative, that is, more values are above the line than below. The largest single annual increase in the consumption of bio-heating oil occurred in 2017, when the consumption of this energy source increased by $185.71 \%$ on the 2016 level. This reflected the airport's heating requirement in 2017. Figure 14 shows that there was a single annual decrease in the consumption of bio-heating oil during the study period. This decrease was recorded in 2019, when the annual consumption of bio-heating oil decreased by $-1.56 \%$ on the 2018 level, due to the lower heating requirement (Figure 14).

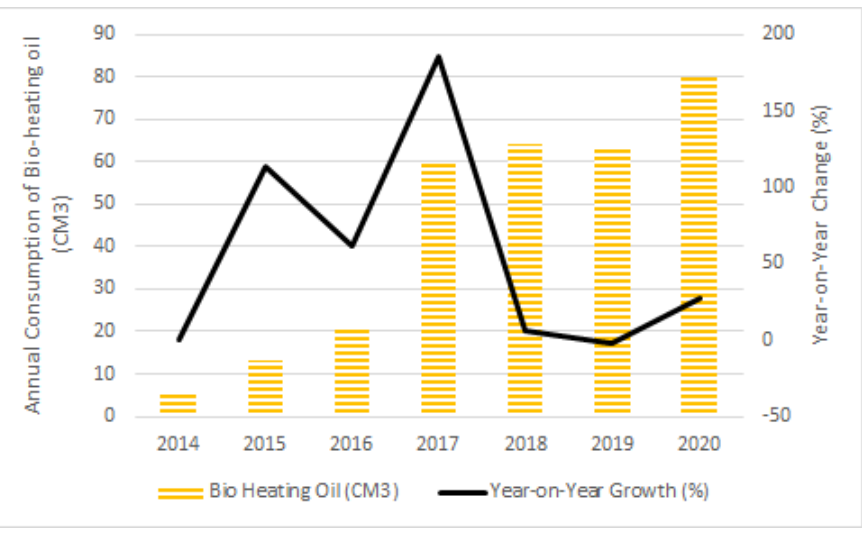

Fig. 14: The annual bio-heating oil consumption at Oslo Airport Gardermoen and year-on-year change (\%): 2014 2020. Source: Data derived from Oslo Airport AS (2016, 2021).

Bio-heating oil offers users several environmental-related advantages. Bio-heating oil is a clean burning alternative fuel, that is produced from both domestic and renewable resources. Biofuel contains no petroleum, and it can be blended at any level with petroleum diesel to create a biofuel blend. Bio heating oil is also considered safe and provides a cleaner, more complete, and energy-efficient burn. This fuel source is a renewable energy source that is environmentally friendly. A further advantage is that bioheating oil reduces global warming gas emissions; it is also non-toxic, biodegradable, and suitable for sensitive environments. In addition. Bio-heating oil is essentially free of sulphur and aromatics. A final advantage is that bio heating oil extends equipment life and reduces periodic maintenance of the (Apgar Oil, 2021).

4.11.2 Annual Consumption of Biofuel for Oslo Airport Gardermoen Vehicles

An important metric in the airport industry is the airport vehicles and ground service vehicles that have been converted to energy efficient types and is an indicator of airport's objective to reduce energy consumption, and the use of fossil-based fuels. Consequently, many airports located throughout the world have decided to convert their airport vehicles to more energy efficient vehicles (Hazel et al, 2016).

Through a framework agreement, advanced biodiesel is purchased by Oslo Airport Gardermoen that satisfies the European Union's sustainability criteria and this biodiesel is also guaranteed without palm oil or palm oil products. 
Advanced biodiesel is used at the airport in vehicles that cannot be easily electrified, for example, snow blowers and sweepers. At the end of 2020, the vehicle fleet of administrative vehicles at Oslo Airport Gardermoen was comprised of 23 zero-emission vehicles (Oslo Lufthaven, 2021).

Figure 15 shows that Oslo Airport Gardermoen began using biofuels for its vehicles in 2015 and continued to use these fuels over the remainder of the study period. As can be seen in Figure 15, there was a general upward trend in the annual consumption of biofuels with a pronounced spike recorded in $2016(+822.22 \%)$. There was just one year when the annual biofuels decreased on a year-on-year basis, and this decrease occurred in 2020, when the annual consumption decreased by $-47.67 \%$, due to the reduced vehicle fuel requirement. From an environmental perspective, biofuels can reduce a firm's consumption of fossil fuels, and hence, reduce carbon dioxide $\left(\mathrm{CO}_{2}\right)$ emissions. This is because biofuels are carbon neutral (Hanaki \& Portugal-Pereira, 2018). In 2020, for example, the use of zero emission vehicles at the airport resulted in a reduction in greenhouse gas emissions of 1,439 tons of carbon dioxide $\left(\mathrm{CO}_{2}\right)$ (Oslo Lufthaven, 2021).

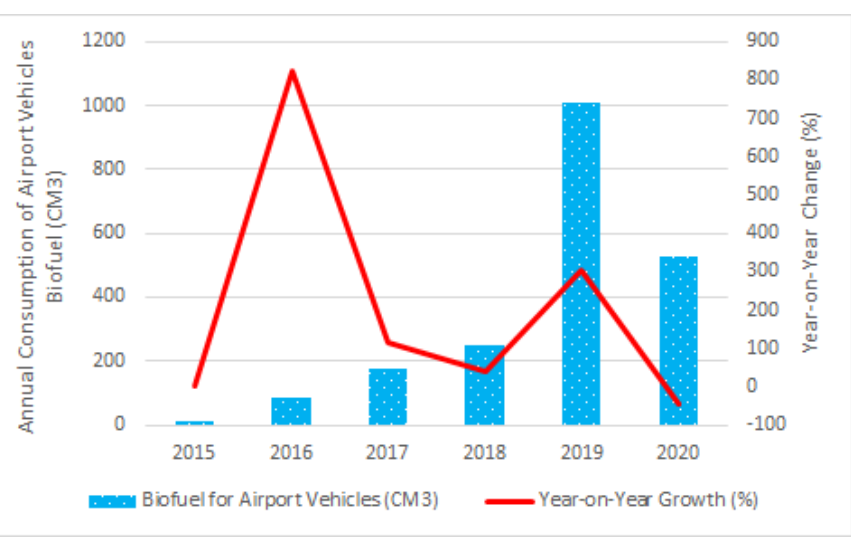

Fig.15: The annual bio-fuel consumption for Oslo Airport Gardermoen vehicles and year-on-year change (\%): 20152020. Source: Data derived from Oslo Airport AS (2016, 2021).

4.11.3 Annual Consumption of Fuel for Fire Drills at Oslo Airport Gardermoen vehicles

In the air transport industry, the incidences of fires and emergencies occurring at an airport are often quite rare, however instances of fires and emergencies, particularly on aircraft, the fire fighting and rescue capabilities at an airport may mean the difference between life and death for pilots, passengers, and other associated airport personnel (Young \& Wells, 2011). It is important to note that there is a finite probability that an accident may occur sooner or later. Many accidents have occurred during take-off and landing, that is, they are often in the vicinity of the airport. Consequently, the airport operator must be fully prepared for such an eventuality (Kazda \& Caves, 2015). The degree of firefighting and rescue protection is dependent upon the size of the largest aircraft operating to the airport together with the frequency of operation (Ashford et al., 2013). Importantly, in accordance with the provisions of Annex 14 to the 1944 Chicago Convention on International Civil Aviation- Aerodromes, Volume I Aerodrome Design and Operations, Member States of the International Civil Aviation Organization are required to provide rescue and firefighting equipment and services at an airport. All personnel (regular and/or auxiliary) provided for aircraft rescue and firefighting duties, should be fully trained in the performance of their duties, and operate under the direction of a designated chief of emergency crew (International Civil Aviation Organization, 2014).

The total annual consumption of paraffin and Jet A1 aircraft fuel for fire drills at Oslo Airport Gardermoen and the year-on-year change (\%) from 2005 to 2020 are presented in Figure 16. Figure 16 shows that there has largely been a downward trend in the amount of paraffin/Jet A1 fuel used for fire drills at Oslo Airport Gardermoen. This is demonstrated by the year-on-year percentage change line graph, which is more negative than positive, that is, more values are below the line than above. Figure 16 shows that there was quite a large increase in this fuel source in 2006 when its consumption increased by $60.51 \%$ on the 2005 levels. The single largest annual decrease in paraffin/Jet A1 fuel for fire drills was recorded in 2014, when the amount of this fuel source decreased by $38.86 \%$ on the 2013 level. Figure 16 shows that there were no reported usage of paraffin and Jet A1 aircraft fuel for fire drills at Oslo Airport Gardermoen during 2019 and 2020 .

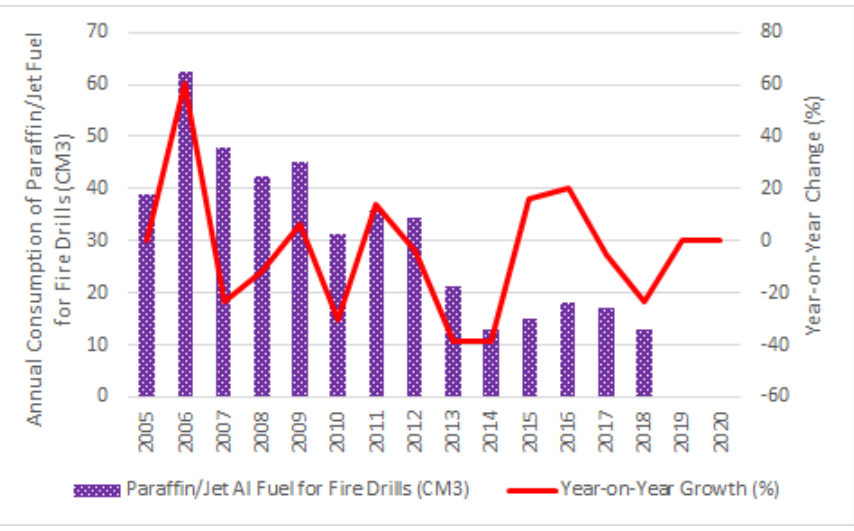

Fig.16: The annual consumption of fuel (paraffin/Jet A1) for fire drills at Oslo Airport Gardermoen and year-onyear change (\%): 2005-2020. Source: Data derived from Oslo Airport AS (2008, 2011, 2016, 2021). 
Figure 17 presents the total annual consumption of propane fuel that is used for fire drills at Oslo Airport Gardermoen and the year-on-year change (\%) from 2005 to 2020. As can be observed in Figure 6, the annual consumption of propane for fire drills at Oslo Airport Gardermoen declined from a high of $2.6 \mathrm{~cm} 3$ to zero in both 2019 and 2020. Figure 17 shows that there were two pronounced spikes in the consumption of propane, and these were recorded in $2010(+46.15 \%)$ and in 2018 $(+200 \%)$, respectively. Figure 17 also shows that there were significant decreases in the amount of propane used for fire drills at the airport. These decreases occurred in $2006(-11.53 \%), 2007$ (-39.13\%), 2011 (-63.15\%), 2013 ($14.28 \%), 2015(-33.33 \%)$, and in $2016(-25 \%)$ (Figure 17). As noted in Figure 17, the volume of paraffin and Jet A1 fuel have been the primary sources for fire drills at the airport.

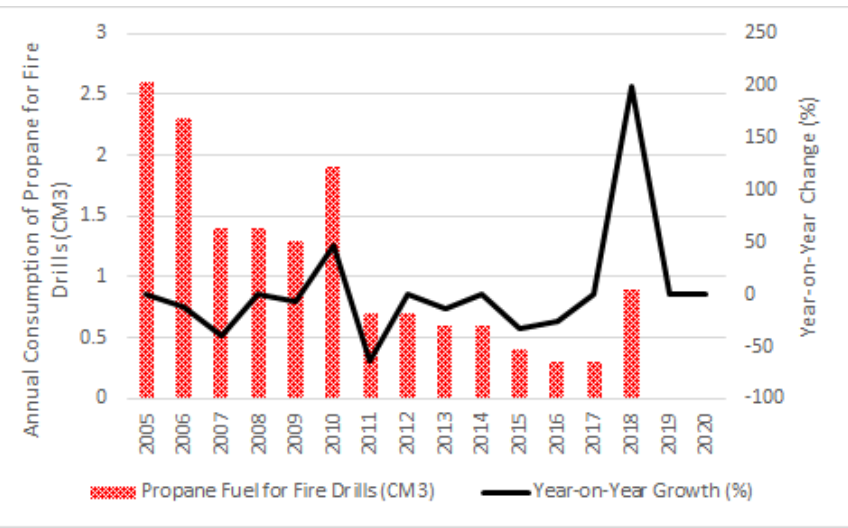

Fig. 17: The annual consumption of fuel (propane) for fire drills at Oslo Airport Gardermoen and year-on-year change (\%): 2005-2020. Source: Data derived from Oslo Airport AS (2008, 2011, 2016, 2021).

4.11.4 Annual Consumption of Fuel for Oslo Airport Gardermoen vehicles

The annual consumption of fuel for Oslo Airport Gardermoen vehicles and the year-on-year change (\%) from 2005 to 2020 are presented in Figure 18. As can be observed in Figure 18, the airport's annual consumption of fuel for its fleet of vehicles has oscillated throughout the study period reflecting varying annual vehicle fuel requirements. The largest single annual increase was recorded in 2014, when the vehicle total fuel consumption increased by $35.02 \%$ on the previous year's level. Figure 18 shows that there was a significant decrease in this fuel source in $2019(-74.87 \%)$ and $2020(-79.13 \%)$, respectively. In these later years, the airport had transitioned to biofuel. The third most significant decrease in vehicle fuel consumption occurred in 2013, when the total vehicle fuel consumption decreased by $19.42 \%$ on the 2012 levels (Figure 18).

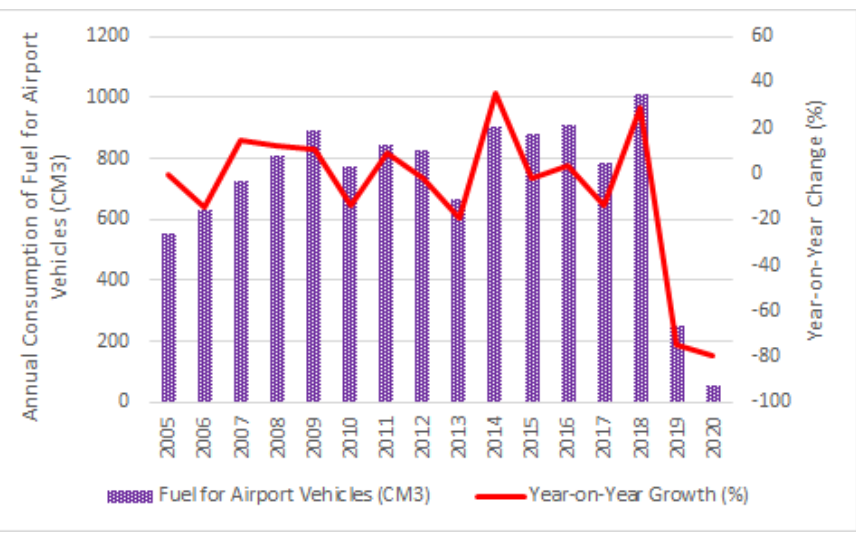

Fig.18: The annual fuel consumption for Oslo Airport Gardermoen vehicles and year-on-year change (\%): 2005 2020. Source: Data derived from Oslo Airport AS (2008, 2011, 2016, 2021).

4.11.5 Annual Heating Oil/Diesel Consumption at Oslo Airport Gardermoen

The total annual heating oil/diesel consumption at Oslo Airport Gardermoen together with the associated year-onyear change (\%) for the period 2005 to 2020 is presented in Figure 19. As can be observed in Figure 19, the airport's annual consumption has declined from a high of 682 cubic metres in 2005 to a low of 26 cubic metres in 2020. Figure 19 also shows that there were three years in the study period where there were pronounced increases in the yearon-year consumption. These increases occurred in 2007 $(+44.35 \%), 2010(+36.91 \%)$, and in $2017(+155.49 \%)$, respectively (Figure 19). The higher annual consumption of heating oil/diesel is reflective of the climatic conditions experienced in Oslo during these years.

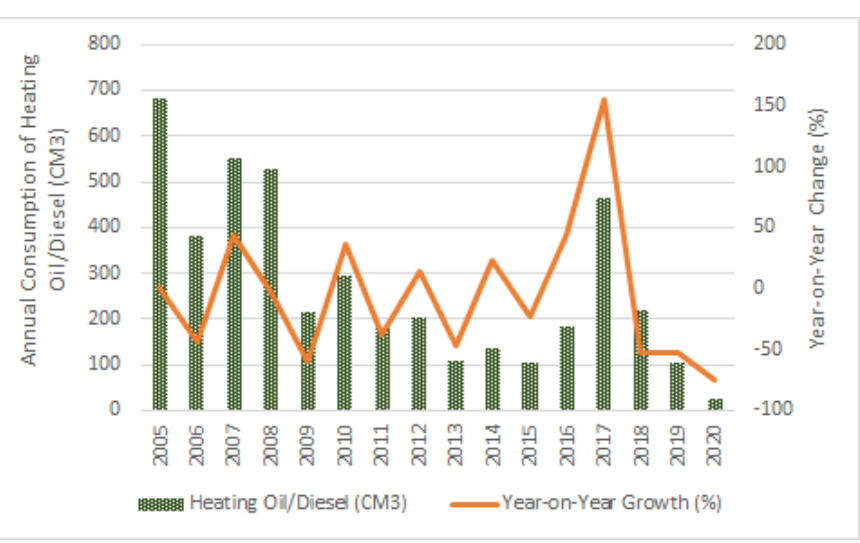

Fig.19: The annual heating oil/diesel consumption at Oslo Airport Gardermoen and year-on-year change (\%): 2005 2020. Source: Data derived from Oslo Airport AS (2008, 2011, 2016, 2021). 
4.11.6 Annual Aircraft Jet Fuel Consumption at Oslo Airport Gardermoen

The total annual aircraft jet fuel consumption at Oslo Airport Gardermoen from 2005 to 2020 and the year-onyear change is presented in Figure 20. As can be observed in Figure 20, there has been an overall upward trend in jet fuel consumption at the airport, which reflects the growth in the annual aircraft movements as well as the larger sizes of the aircraft using the airport. The overall increase in aircraft jet fuel consumption at the airport is demonstrated by the year-on-year percentage change line graph, which is more positive than negative, that is, more values are above the line than below. The highest annual single increase in aircraft jet fuel consumption was recorded in 2006, when the annual aircraft jet fuel consumption increased by $14.91 \%$ on the 2013 level. During the study period, there were three years where the annual aircraft jet fuel consumption declined on a year-on-year basis. These decreases were recorded in $2009(-5.68 \%), 2015(-3.1 \%)$, and in $2020(-58.47 \%)$ (Figure 20). The pronounced drop in 2020 was due to the significant reduction in aircraft movements due to the downturn in traffic and flights because of the Corona virus pandemic.

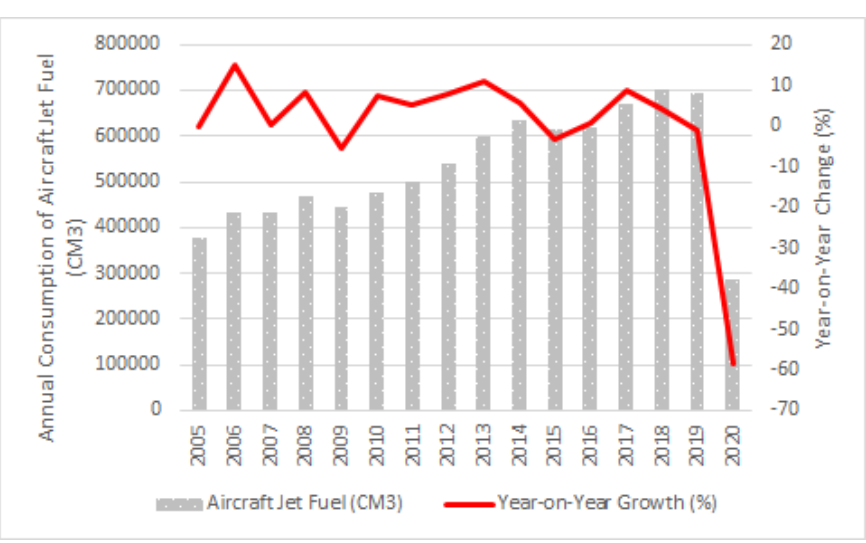

Fig.20: The annual aircraft jet fuel consumption at Oslo Airport Gardermoen and year-on-year change (\%): 20052020. Source: Data derived from Oslo Airport AS (2008, 2011, 2016, 2021).

An important development in the air transport industry in recent trends has been increasing trend by airports and airlines to use aviation biofuel as a key environment

sustainability measure (Baxter et al., 2020). Indeed, the growing concerns of climate change and energy supply have been driving the production of more sustainable aviation fuels (Brooks et al., 2016). As a result, alternative jet fuel (AJF) technologies have gained strong interest, and thus, are increasingly being viewed as a way for the airline industry to achieve large, near-term emissions reductions (Staples et al., 2014). Aviation biofuels are therefore becoming an important substitute for fossil fuel in the airline industry. Aviation biofuels offer several advantages including sustainability, they are environmentally friendly, and they offer good adaptability ( $\mathrm{Su}$ et al., 2015). Considering these advantages, the aviation industry has acknowledged the importance of sustainable biofuels as being the key long-term technology for decarbonizing aviation (Fregnani \& Andrade, 2017).

Oslo Airport became the world's first airport to offer sustainable jet biofuel to all airlines serving the airport in 2016. The jet biofuel is supplied by Air BP. Lufthansa Group, SAS and KLM have signed agreements to purchase the fuel. Norwegian airport operator Avinor AS played a vital role in the commercial offtake agreements by offering incentives for all flights at Oslo Airport that use sustainable jet fuel. The aviation biofuel is produced by Neste in accordance with the framework of the demonstration project ITAKA. The first batch of this sustainable jet fuel is made from camelina oil that is Roundtable on sustainable biomaterials (RSB) certified (Airport Technology, 2016). Airlines that participate in this initiative are rewarded with lower carbon dioxide $\left(\mathrm{CO}_{2}\right)$ taxes on domestic flights in Norway and the aviation biofuel is also exempted from the European Union (EU) quota system (Biofuels International, 2016). In addition, Avinor AS has set a goal that by 2030 goal, thirty per cent of aviation fuel consumed in Norway. This would equate to around 400 million litres (Mosvold Larsen, 2017).

\subsection{Energy Conservation Measures at Oslo Airport Gardermoen}

Oslo Airport Gardermoen has historically placed a high focus on identifying the opportunities to conserve energy, and thus, mitigate or minimize any environmentally harmful impacts associated with its energy consumption. Energy conservation is the saving of energy by a firm through the elimination of wasteful use, making more efficient use of energy, or reducing the firm's total use of energy (Allaby \& Park, 2007).

In 2007, Oslo Airport Gardermoen implemented a fourth quarter trial set-up for the potential upgrading of lightfittings to long-life light sources. This initiative showed the potential annual savings of $150 \mathrm{MWh}$ in the airport's terminal piers. An additional benefit was the reduced demand for cooling energy (Oslo Lufthaven AS, 2008). During 2008, Oslo Airport Gardermoen modified 142 light fittings in the airport terminal buildings with light fittings that used $10 \%$ less energy. This initiative resulted in an annual energy saving of $17 \mathrm{MWh}$, other benefits included reduced heat emission, improved technical properties and a six-fold increase in the lighting's service life (Oslo Lufthaven AS, 2009). In 2009, Oslo Airport Gardermoen 
installed new light fittings on the airport's railway platforms. The new light fittings delivered a 43 per cent saving in the lighting energy consumption. Also, during 2009, the airport terminals and other buildings lighting control systems were improved. In addition, the improved control of the street heating system located outside the Terminal Building reduced the annual thermal energy consumption by an estimated 600-800 MWh (Oslo Lufthaven AS, 2010).

Airports around the world are increasingly transitioning to the use of light emitting diodes (LED) lighting systems (Bullough, 2012; Freyssinier, 2014; Taylor, 2011). Oslo Airport Gardermoen is one such airport that has followed this trend. LED lighting can improve the quality of lighting and comfort of building occupants, whilst at the same time deliver energy savings that are beyond improved source efficiency (United States Department of Energy, 2019). In 2010, Oslo Airport Gardermoen's up-light fixtures consisting of 1000 watts lamps located in the airport terminal were modified and this resulted in annual saving of 552 MWh. During December 2010, a series of downlight fixtures were replaced with LED downlights and this new lighting technology was estimated to provide an annual energy saving of $33 \mathrm{MWh}$ (Oslo Lufthaven AS, 2011). Oslo Airport Gardermoen continued its program of installing LED lighting during 2011, when the airport completed the modification of 1000 watt light fixtures in the airport terminal as well as the replacement of downlight fixtures with LED lamp in the arrival hall. These lighting measures enabled the airport to achieve a $552 \mathrm{MWh}$ and $43 \mathrm{MWh}$ energy savings, respectively (Oslo Lufthaven AS, 2012).

In 2012, Oslo Airport Gardermoen modified the heat exchangers in the airport's terminal building ventilation system. Other energy saving measures implemented in 2012 included the modification of 100 downlight fixtures in the international arrivals hall, which resulted in a forty percent energy saving. These two energies saving measures produced an annual saving of 1,452 MWh. The airport also installed LED flood lighting in the general aviation terminal, which is located to the west airport, and this measure resulted in annual energy savings of $21 \mathrm{MWh}$ (Oslo Lufthaven AS, 2013). During 2013, Oslo Airport Gardermoen converted the remaining 100 uplights in the international arrival's hall to more energy efficient lighting, which delivered an annual energy saving of 213 MWh. Also, in 2013, the airport modified 280 uplights in Pier East and Pier West and this lighting modification resulted in around $70 \%$ of these lights becoming operational resulting in a reduction in consumption of approximately $50 \mathrm{MWh}$ per annum. Fluorescent lights were also replaced in the airport's administration building in 2013 and this measure enabled the airport to reduce energy consumption by $25 \mathrm{MWh}$ per annum (Oslo Lufthaven AS, 2014).

During 2014, Oslo Airport Gardermoen continued its program of implementing further energy saving measures that delivered an annual saving in energy consumption of 1,265 MWh. The energy saving measures implemented in 2014 included the modification of uplights in the airport's Pier East and Pier West as well as the upgrading of LED lights in the terminal and on the runways. In addition, heat exchangers in the airport's ventilation system were modified and the air conditioning unit was replaced with a free cooling unit (Oslo Lufthaven AS, 2015). The energy saving measures implemented by Oslo Airport Gardermoen in 2015 resulted in an annual energy reduction of $216 \mathrm{MWh}$. These measures included the replacement of halogen runway lights with LED lighting. Around 800 runway lights were replaced, and this initiative delivered an annual energy saving of $149 \mathrm{MWh}$. The airport also replaced a ventilation unit with a free cooling unit, saving up to $67 \mathrm{MWh}$ per annum. In addition, the airport's heat exchange, which comprised a free exchanger and low-temperature heat pump, as well as treated wastewater from the municipality of Ullensaker, became operational in 2015. The treated wastewater acts as a heat source during the winter period and as a heat sink during cooling throughout the summer period (Oslo Lufthaven AS, 2016).

A range of energy savings measures were implemented at the airport in 2016. Around 867 halogen runway lights were replaced with LED lights providing a reduction in power consumption of $117 \mathrm{MWh}$ per annum. In addition, some LED lights were also replaced in the passenger terminal and this initiative resulted in an annual energy saving of $68 \mathrm{MWh}$. The most significant energy saving measure in 2016, however, was the replacement of heat recovery units in two ventilation systems. The airport switched from battery recovery units to much more energy efficient rotary recovery units. The annual energy saving from this initiative was $710 \mathrm{MWh}$. Also, in 2016, the temperature in Hangar 8 was reduced to further save energy and power during the winter season. The annual saving for this measure was estimated to be $87 \mathrm{MWh}$ (Oslo Lufthaven AS, 2017).

Oslo Airport Gardermoen continued its program of implementing further energy saving measures during 2017 and these measures delivered total annual energy savings of 2,398 MWh. The measures included the further replacement of halogen lights with LED lighting. In total, 1,100 lane lights were replaced as part of the lighting upgrade program, which resulted in the annual power consumption of around 198 MWh. Furthermore, some 
replacements were made to the airport terminal's LED lighting, which contributed to an annual energy saving of $250 \mathrm{MWh}$. The largest single annual energy saving measure, however, was the replacement of lighting system in the airport's parking lot P-11. This upgrade involved the entire lighting system of 1,250 luminaires being replaced with more efficient LED lighting. Each luminaire has a motion detector sensor that dims down the light if there is no nearby activity. This lighting project delivered annual energy savings of around 1,950 MWh (Oslo Lufthaven AS, 2018).

During 2018, the range of additional energy saving measures enabled Oslo Airport Gardermoen to reduce its energy consumption by 5,102 MWh. This significant annual saving was achieved through the better monitoring and controlling of its energy requirements. This was done by setting the time control and night reduction in the airport's ventilation system, and through the pulses of lighting. In 2018, the largest energy savings came from the replacement of the entire lighting system in the airport's parking garage P-10. This project involved the replacement of 6,224 luminaires with more efficient LED lighting with motion detection capability. This lighting upgrade resulted in an annual energy saving of 3,000 MWh per annum. Also, in 2018, two ventilation units in the Pier West terminal were replaced with a larger unit that had a much higher heat recovery and more efficient fans. In addition, a lot of old lighting was also changed in other buildings, and the replacement of lane lighting with LED lights continued in 2018. Overall, these measures resulted in a reduction of 1,300 MWh/year (Oslo Lufthaven AS, 2019).

Oslo Airport Gardermoen defined and implemented a range of new energy saving measures in 2019 that enabled the airport to further reduce its energy consumption by 1.4 GWh/year. During 2019, new LED lighting was installed in the airport's sweeper halls and in part of the Pier Makeup Zone (PMZ). Furthermore, a contract was signed for the replacement flood lighting around the airport terminal building with new LED lighting. This measure would not only deliver safety benefits, it will also save electricity, and reduce the airport's overall power consumption. In 2019, three new energy-efficient rotor recyclers in the passenger terminal were installed together with a new heat exchanger that helps the airport to recover around 3-4 GWh of heat energy from the plant located at Ullensaker. Other energy saving measures implemented in 2019 included the installation of blanking pedestals on the existing lights in Hangar 8, the installation of motion sensors and night lowering in Pir Syd, the night lowering of lighting in Pier Norda and SBV, together with the automatic control of ground heating systems at the airport's apron (Oslo Lufthaven AS, 2020). The airport apron comprises the individual aircraft stands that interface with the airport terminal building(s) and where aircraft are ground handled in between flights (Budd \& Ison, 2017). When combined, these energy saving measures enabled Oslo Airport Gardermoen to reduce its energy consumption by around $2 \mathrm{GWh}$ in 2019 (Oslo Lufthaven AS, 2020).

In August 2020, eight electric 18-meter buses were delivered to Oslo Airport Gardermoen. These new buses were a replacement for eight fossil fuel-powered buses. The electric buses are to be used to carry passengers between the airport terminal and remotely parked aircraft (Oslo Lufthaven AS, 2021).

\section{CONCLUSION}

Using an instrumental case study research approach this study has examined Oslo Airport Gardermoen, Norway's principal air traffic hub, environmentally sustainable energy management. The study covered the period 2005 to 2020. The documents gathered for the case study were analyzed using document analysis.

The case study revealed that Oslo Airport Gardermoen has multiple energy sources. The airport purchases electricity that is used for the airport's specific installations as well as for the airport's electrode boiler and compressors and pumps. The airport also purchases heating and cooling energy from external vendors, such as, Statkraft Varme AS. The non-renewable energy sources include aircraft jet fuel, heating oil/diesel, fuel and biofuels for the airport's vehicles, and supplies of paraffin/Jet A1 fuel and propane, with the latter fuel sources being used for the fire drills conducted at the airport.

Over the study period, the airport's total consumption increased from $72.8 \mathrm{GWh}$ in 2005 to $99 \mathrm{GWh}$ in 2020. The highest single annual consumption of electricity was recorded in 2018, when a total of $120 \mathrm{GWh}$ of electricity was consumed at the airport. The annual electricity consumption per enplaned passenger fluctuated throughout the study period. The annual electricity consumption per aircraft movement exhibited an upward trend, which was in line with larger aircraft types using the airport plus the increased aircraft movements at the airport..

The heating and cooling energy purchased by the airport is influenced by weather patterns, and thus, the heating and cooling requirements reflected the necessity to heat or cool the airport's buildings. The case study revealed that Oslo Airport Gardermoen has been transitioning to biofuels as the energy source for its heating requirements. Biofuels are a cleaner, more complete, and energy efficient burning 
source. The use of biofuels enables users to reduce their greenhouse gas (GHG) emissions. The use of biofuels for the airport's vehicles will also result in a reduction in greenhouse gas (GHG) emissions at the airport.

The case study found that there has been an overall upward trend in jet fuel consumption at Oslo Airport Gardermoen. As noted in the case study, there has been a general increase in the number of aircraft movements at the airport, and these increases translate into higher jet fuel consumption.

The case study also shows that throughout the study period Oslo Airport Gardermoen has identified and implemented a wide range of energy conservation measures and technologies that have further enabled the airport to mitigate its impact on the environment. The energy conservation measures include the installation of LED lighting in the airport terminals and administration building, the installation of LED flood lighting in the airport's general aviation terminal, and the installation of LED lighting on the airport's runways and taxi lanes. LED lighting was also installed in the airport's car parking lots (P-1 and P-10). Other energy conservation measures implemented throughout the study period included the replacement of a ventilation unit with a free cooling unit, an upgrade to the airport's heat exchange which consisted of a free exchanger and low temperature pump that used treated wastewater from the municipality of Ullensaker, the introduction of more energy efficient rotary heat recovery units, and the replacement of flood lighting around the airport's terminal building with new LED lighting. The airport also installed blanking pedestals on the existing lights in Hangar 8, the installation of motion sensors and night lowering in Pir Syd, the night lowering of lighting in Pier Norda and SBV, as well as the automatic control of ground heating systems at the airport's apron.

Another important energy and environment-related measure has been the use of sustainable aviation fuels. As noted earlier, Oslo Airport became the world's first airport to offer sustainable jet biofuel to all airlines serving the airport. The case study also revealed that in 2018, the drilling of two deep water geothermal wells 1,500 metres in depth was completed. These wells are used to supply the ground heating system located in the airport's aircraft engine test area.

\section{REFERENCES}

[1] Aircraft Commerce. (2015). 787 \& A350 XWB: How do they reduce maintenance costs? Aircraft Commerce, 102, 16-23.
[2] Aircraft Commerce. (2016). Fuel burn \& operating performance of the 787-8, 787-9 and A350-900. Aircraft Commerce, 108, 16-27.

[3] Airport Technology. (2016). Oslo Airport becomes world's first airport to supply sustainable jet fuel to airlines. Retrieved from https://www.airporttechnology.com/uncategorised/newsoslo-airportbecomes-worlds-first-airport-to-supply-sustainable-jetfuel-to-airlines-4793272/.

[4] Airport Technology. (2017a). Oslo Airport Terminal 2. Retrieved from https://www.airporttechnology.com/projects/oslo-airport-terminal-2/.

[5] Airport Technology. (2017b). Sustainable success: Oslo Airport opens 'world's greenest' terminal. Retrieved from https://www.airport-

technology.com/features/featuresustainable-success-osloairport-opens-worlds-greenest-terminal-5885304/.

[6] Akyüz, M.K., Altuntaş, Ö., \& Söğüt, M. Z. (2017). Economic and environmental optimization of an airport terminal building's wall and roof insulation. $\begin{array}{lll}\text { Sustainability, } & 9(10), & \end{array}$ https://doi.org/10.3390/su9101849

[7] Akyüz, M.K., Altuntas O., Sogut M.Z, Karakoc T.H., \& Kurama, S. (2018). Determination of optimum insulation thickness for building's walls with respect to different insulation materials: A case study of International Hasan Polatkan Airport terminal. International Journal of Sustainable Aviation, 4(2), 147-161.

[8] Alba, S.O., \& Manana, M. (2017). Characterization and analysis of energy demand patterns in airports. Energies, 10(1), 119. https://doi.org/10.3390/en10010119

[9] Allaby, C., \& Park, M. (2007). A dictionary of environment and conservation. Oxford, UK: Oxford University Press.

[10] Ang, S.H. (2014). Research design for business \& management. London, UK: SAGE Publications; 2014.

[11] Apgar Oil. (2021). What is bioheat? And is it better than heating oil? Retrieved from https://www.apgaroil.com/bioheat-better-heating-oil/.

[12] Appold, S.J., \& Kasarda, J.D. (2011). Seeding growth at airports and airport cities: Insights from the two-sided market literature. Research in Transportation Business \& Management, $\quad 1(1), \quad 91-100$. https://doi.org/10.1016/j.rtbm.2011.06.011

[13] Ashford, N.J., Martin Stanton, H.P., Moore, C.A., Coutu, P., \& Beasley, J.R. (2013), Airport operations (3rd ed.). New York, NY: McGraw-Hill.

[14] Asian Aviation. (2012). 747-8I enters commercial service. Retrieved from https://asianaviation.com/747-8i-enterscommercial-service/.

[15] Avinor AS. (2021a). About Oslo Airport: Facts and figures. Retrieved from https://avinor.no/en/corporate/airport/oslo/about-us/aboutoslo-airport/tall-og-fakta. 
[16] Avinor AS. (2021b). About Oslo Airport: Traffic statistics. Retrieved from https://avinor.no/en/corporate/airport/oslo/aboutus/traffic_statistics/trafikkstatistikk.

[17] Avinor AS. (2021c). Energy. Retrieved from https://avinor.no/en/corporate/airport/oslo/communityand-environment/energi/enok.

[18] Avinor AS. (2021d). Environmental management. Retrieved from: https://avinor.no/en/corporate/airport/oslo/communityand-environment/miljostyring/.

[19] Avinor AS. (2021e). The new Oslo Airport 2017. Retrieved from https://avinor.no/en/corporate/airport/oslo/development/th is-is-new/this-is-new.

[20] Avinor AS. (2021f). Renewable energy. Retrieved from https://avinor.no/en/corporate/airport/oslo/communityand-environment/energi/fornybar-energi.

[21] Barrett, S., Devita, P., Ho. C., \& Miller, B. (2014). Energy technologies' compatibility with airports and airspace: Guidance for aviation and energy planners. Journal of Airport Management, 8(4), 318-326.

[22] Baxter, G. (2021). Mitigating an airport's carbon footprint through the use of "green" technologies: The case of Brisbane and Melbourne Airports, Australia. International Journal of Environment, Agriculture and Biotechnology, 6(6), 29-39. https://dx.doi.org/10.22161/ijeab.66.4

[23] Baxter, G., Srisaeng, P., \& Wild, G. (2018a). An assessment of airport sustainability, Part 2-Energy management at Copenhagen Airport. Resources, 7(2), 32. https://doi.org/10.3390/resources7020032

[24] Baxter, G., Srisaeng, P., \& Wild, G. (2018b) Sustainable airport energy management: The case of Kansai International Airport. International Journal for Traffic and Transport Engineering, 8(3), 334-358.

[25] Baxter, G., Srisaeng, P., \& Wild, G. (2020). The use of aviation biofuels as an airport environmental sustainability measure: The case of Oslo Gardermoen Airport. Magazine of Aviation Development, 8(1), 6-14. https://doi.org/10.14311/MAD.2020.01.01

[26] Biofuels International. (2016). Norway's Oslo Airport begins jet biofuel delivery for all airlines. Retrieved from https://biofuels-news.com/news/norways-oslo-airportbegins-jet-biofuel-delivery-for-all-airlines/.

[27] Birhanu, Z.K., Kitterød, N-O., Krogstad, H.E., \& Kværn $\varnothing$, A. (2015). Temperature boundary conditions for ATES systems. AIP Conference Proceedings, 1648, 030032. https://doi.org/10.1063/1.4912349

[28] Boon, T. (2020). Which airlines fly the Boeing 787-10? Retrieved from https://simpleflying.com/boeing-787-10airlines/.

[29] Bråthen S., \& Fuglum K. (2016). Developing airports in a long-term perspective: The case of Troms $\varnothing$, Norway. In
G. Williams \& S. Bråthen (Eds.), Air transport provision in remoter regions (pp. 221-230). Abingdon, UK: Routledge.

[30] Brooks, K.P., Snowden-Swan, 1.J., Jones, S.B., Butcher, M.J., Lee, J.S.J., Anderson, D.M., Frye, J.G., Holladay, J.E., Owen, J., Harmon, L., Burton, F., Palou-Rivera, I., Plaza, J., Handler, R., \& Shonnard, D. (2016). Lowcarbon aviation fuel through the alcohol to jet pathway. In C. Chuck (Ed.), Biofuels for aviation: Feedstocks, technology and implementation (pp. 109-146). London, UK: Academic Press.

[31] Budd, L., \& Budd, T. (2013). Environmental technology and the future of flight. In L. Budd, S. Griggs \& D. Howarth (Eds.), Sustainable aviation futures (pp. 87-107). Bingley, UK: Emerald Group Publishing.

[32] Budd, L., \& Ison, S. (2017). Airfield design, configuration, and management. In L. Budd \& S. Ison, (Eds.), Air transport management: An international perspective (pp. 59-77). Abingdon, UK: Routledge.

[33] Bullough, J. D. (2012). Light-emitting diode airfield lighting systems. Retrieved from https://www.internationalairportreview.com/article/10414 /light-emitting-diode-airfield-lighting-systems/.

[34] Business Traveller. (2017). Oslo airport opens terminal extension. Retrieved from https://www.businesstraveller.com/businesstravel/2017/04/27/oslo-airport-opens-terminal-extension/.

[35] Cardona, E., Piacentino, A., \& Cardona, F. (2006). Energy saving in airports by trigeneration. Part I: Assessing economic and technical potential. Applied Thermal Engineering, 26(14-15), 1427-1436. https://doi.org/10.1016/j.applthermaleng.2006.01.019

[36] Climates to Travel. (2012). Climate - Oslo, Norway. Retrieved from https://www.climatestotravel.com/climate/norway/oslo.

[37] Comendador, V.F.G., Valdés, R.M.A., \& Lisker, B. (2019). A holistic approach to the environmental certification of green airports. Sustainability, 11(15), 4043. https://doi.org/10.3390/su11154043

[38] Culberson, S.D. (2011) Environmental impacts of airports. In N.J. Ashford, S.A. Mumayiz \& P.H. Wright (Eds.), Airport engineering: Planning, design, and development of 21st century airports (pp. 704-738) (4th ed.). Hoboken, NJ: John Wiley \& Sons.

[39] Daley, B. (2016). Air transport and the environment. Abingdon, UK: Routledge.

[40] Derrington, M.L. (2019). Qualitative longitudinal methods: Researching implementation and change. Thousand Oaks, CA: SAGE Publications.

[41] Dentch, M.P. (2016). The ISO 14001:2015 handbook: Using the process approach to building an environmental management system. Milwaukee, WI: Quality Press

[42] de Rubeis, T., Nardi, J., Paoletti, D., Di Leonardo, A., Ambrosini, D., Poli, R., \& Sfarra, S. (2016). Multi-year 
consumption analysis and innovative energy perspectives: The case study of Leonardo da Vinci International Airport of Rome. Energy Conversion and Management, 128, 261272. https://doi.org/10.1016/j.enconman.2016.09.076

[43] Dube, K., Nhamo, G., \& Chikodzi, D. (2021). COVID-19 pandemic and prospects for recovery of the global aviation industry. Journal of Air Transport Management, 92,

102022 .

https://doi.org/10.1016/j.jairtraman.2021.102022

[44] Eggen, G., \& Vangsnes, G. (2006). Heat pump for district cooling and heating at Oslo Airport, Gardermoen [Aquifer thermal energy systems (ATES)]. Retrieved from https://www.osti.gov/etdeweb/biblio/20886519.

[45] Energy Australia. (2021). Energy recovery fact sheet. Retrieved from https://www.energyaustralia.com.au/sites/default/files/202 0-11/Energy\%20Recovery_Fact_\%20Sheet.pdf.

[46] Efthymiou, M., \& Papatheodorou, A. (2018). Evolving airline and airport business models. In N. Halpern \& A. Graham (Eds.), The Routledge companion to air transport management (pp. 122-135). Abingdon, UK: Routledge.

[47] Feldman, J. (1998). 25 years to life. Air Transport World, 35(9), 91-96.

[48] Ferrulli, P. (2016). Green airport design evaluation (GrADE) - Methods and tools improving infrastructure planning. Transportation Research Procedia, 14, 37813790. https://doi.org/10.1016/j.trpro.2016.05.463

[49] Fregnani, A.T.G., \& Andrade, O. (2017). Aviation initiatives and the relative impact of electric road vehicles on $\mathrm{CO}_{2}$ emissions. Retrieved from https://www.boeing.com/features/innovationquarterly/aug2017/feature-technical-co2.page.

[50] French, H., \& Binley, A. (2004). Snowmelt infiltration: Monitoring temporal and spatial variability using timelapse electrical resistivity. Journal of Hydrology, 297(14), 174-186. https://doi.org/10.1016/j.jhydrol.2004.04.005

[51] Freyssinier, J.P. (2014). The long-term performance of LEDs. International Airport Review, 18, 38-41.

[52] González-Ruiz, J.D., Duque, E., \& Restrepo, J. (2017). Green airport infrastructure in Colombia: Opportunities for public-private partnerships schemes. Pertanika Journal of Science \& Technology, 25, 37 - 46.

[53] Graham, A. (2005). Airport benchmarking: A review of the current situation. Benchmarking: An International Journal, 12(2), 99-111. https://doi.org/10.1108/14635770510593059

[54] Graham, A. (2018). Managing airports: An international perspective (5th ed.). Abingdon, UK: Routledge.

[55] Grover, R.C., \& Grover, S. (2017). Winning the environmental challenge with ISO 14001: 2015: Implementation of an Environmental Management System. Chennai, India: Notion Press.

[56] Hanaki, K., \& Portugal-Pereira, J. (2018) The effect of biofuel production on greenhouse gas emission reductions. In K. Takeuchi, H. Shiroyama, O. Saito \& M. Matsuura (Eds.), Biofuels and sustainability: Holistic perspectives for policymaking (pp. 53-71) Tokyo, Japan: Springer Japan.

[57] Hassett, M., \& Paavilainen-Mäntymäki, E. (2013). Longitudinal research in organizations: An introduction. In M. Hasset \& E. Paavilainen-Mäntymäki (Eds.), Handbook of longitudinal research methods in organisation and business studies (pp. 1-12). Cheltenham, UK: Edward Elgar Publishing.

[58] Hazel, R.A., David Blais, I., Browne, T.J., \& Benzom, D.M. (2016). Resource guide to airport performance indicators. Airport Cooperative Research Program Report 19A. Washington, DC: Transportation Research Board.

[59] Heras-Saizarbitoria, I., Landín, G.A., \& Molina-Azorín, J.F. (2011). Do drivers matter for the benefits of ISO 14001? International Journal of Operations and Production Management, 31(2), 192-216. https://doi.org/10.1108/01443571111104764

[60] Holloway, S. (2016). Straight and level: Practical airline economics (3rd ed.). Abingdon, UK: Routledge.

[61] Iatrou, K., \& Williams, G. (2008). New for old: An analysis of the impact of the new Athens and Oslo airports. Journal of Airport Management, 2(3), 235-248.

[62] International Airport Review. (2010). Oslo Airport Europe's most efficient airport. Retrieved from https://www.internationalairportreview.com/article/3989/ oslo-airport-europes-most-efficient-airport/.

[63] International Civil Aviation Organization. (2014). Airport services manual Part 1: Rescue and firefighting. (4th ed.). Document 9137- AN/898. Montreal, Canada: ICAO.

[64] Jackson, R. (2021). Airbus A380. Barnsley, UK: Pen \& Sword Books.

[65] Janić, M. (2011). Greening airports: Advanced technology and operations. London, UK: Springer Verlag London Limited.

[66] Kazda, T., \& Caves, B. (2015). Airport emergency services. In A Kazda \& R.E Caves (Eds.), Airport design and operation (pp. 427-456) (3rd ed.). Bingley, UK: Emerald Group Publishing.

[67] Kazda, T., Caves, B., \& Kamenický, M. (2015). Environmental control. In A. Kazda \& R.E. Caves (Eds.), Airport design and operation (pp. 457-500) (3rd ed.). Bingley, UK: Emerald Group Publishing.

[68] Kim, S.C., Shin, H.I., \& Ahn, J. (2020). Energy performance analysis of airport terminal buildings by use of architectural, operational information and benchmark metrics. Journal of Air Transport Management, 83, 101762. https://doi.org/10.1016/j.jairtraman.2020.101762

[69] Kumar, A., Aswin, A., \& Gupta, H. (2020). Evaluating green performance of the airports using Hybrid BWM and VIKOR methodology. Tourism Management, 76, 103941. https://doi.org/10.1016/j.tourman.2019.06.016 
[70] Larssen, S., Grønskei, K.E., Gram, F., Hagen, L.O., \& Walker, S.E. (1994). Verification of urban scale timedependent dispersion model with subgrid elements in Oslo, Norway. In S.E. Gryning \& M.M. Millán (Eds.), Air pollution monitoring and application $X$ (pp. 91-99). Boston, MA: Springer.

[71] Ledec, G.C., Rapp, K.W., \& Aiello, R.G. (2011). Greening the wind: Environmental and social considerations for wind power development. Washington, DC: The World Bank.

[72] Lian, J. I. (2010). Network dependency and airline competition - Consequences for remote areas in Norway. Journal of Air Transport Management, 16(3), 137-143. https://doi.org/10.1016/j.jairtraman.2009.07.007

[73] Liu, S., Butler, D., Memon, F.A., Makropoulos, C., Avery, L., \& Jefferson, B. (2010). Impacts of residence time during storage on potential of water saving for grey water recycling system. Water Research, 44(1), 267-277. https://doi.org/10.1016/j.watres.2009.09.023

[74] Liu, X., Zhang, T., Liu, X., Li, L., Lin, L., \& Jiang, Y. (2021). Energy saving potential for space heating in Chinese airport terminals: The impact of air infiltration. Energy, 215(Part 119175. https://doi.org/10.1016/j.energy.2020.119175

[75] Mæx Moe, J. (2018). Using stored snow as cooling at Oslo airport, Norway. Civil Engineering, 171(5), 11-16. https://doi.org/10.1680/jcien.17.00041

[76] Maria Iacus, S., Natale, F., Santamaria, C., Spyratos, S., \& Vespe, M. (2020). Estimating and projecting air passenger traffic during the COVID-19 coronavirus outbreak and its socio-economic impact. Safety Science, 129, 104791. https://doi.org/10.1016/j.ssci.2020.104791

[77] McEntee, F. (2021). How green is hydropower? Retrieved from https://www.sustaineurope.com/how-green-ishydropower-20180229.html.

[78] McCutchen, D.M., \& Meredith, J.R. (1993). Conducting case study research in operations management. Journal of Operations Management, 11(3), 239-256. https://doi.org/10.1016/0272-6963(93)90002-7

[79] Monsalud, A., Ho, D., \& Rakas, J. (2015). Greenhouse gas emissions mitigation strategies within the airport sustainability evaluation process. Sustainable Cities and Society, $\quad 14, \quad 414-424$. https://doi.org/10.1016/j.scs.2014.08.003

[80] Mosvold Larsen, O. (2017). Aviation biofuels at Oslo Airport. Retrieved from https://www.icao.int/Meetings/altfuels17/Documents/Ola v\%20Mosvold\%20Larsen\%20-\%20Avinor.pdf.

[81] National Hydropower Association. (2021). Clean \& sustainable. Retrieved from: https://www.hydro.org/waterpower/why-hydro/clean-andsustainable/\#: : text=Hydropower\%20is\%20a\%20climate $\% 2$ Dfriendly,over\%2038\%20million\%20passenger\%20ca rs.
[82] Neale, B. (2018). What is qualitative longitudinal research? London, UK: Bloomsbury Publishing.

[83] Oates, B.J. (2006). Researching information systems and computing. London, UK: SAGE Publications.

[84] O'Leary, Z. (2004). The essential guide to doing research. London, UK: SAGE Publications.

[85] Norwegian Ministry of Petroleum and Energy. (2021). Energy facts Norway. Retrieved from https://energifaktanorge.no/en/norskenergiforsyning/kraftproduksjon/.

[86] Orth, H., \& Weidmann, O. (2014). Airport cities and airport public transport access: Demand balancing or peak exacerbation? Case of Zurich Airport, Switzerland. Transportation Research Record: Journal of the Transportation Research Board, 2449(1), 24-33. https://doi.org/10.3141\%2F2449-03

[87] Oslo Lufthavn AS. (2008). Environmental report 2007. Retrieved from https://avinor.no/globalassets/_oslolufthavn/om-oslo-lufthavn/omoss/rapporter/en/environmental/Environmental-report2007.

[88] Oslo Lufthavn AS. (2009). Environmental report 2008. Retrieved from https://avinor.no/globalassets/_oslolufthavn/om-oslo-lufthavn/omoss/rapporter/en/environmental/Environmentalreport_2008.pdf.

[89] Oslo Lufthavn AS. (2010). Environmental report 2009. Retrieved from https://avinor.no/globalassets/_oslolufthavn/om-oslo-lufthavn/omoss/rapporter/en/environmental/Environmentalreport_2009.pdf.

[90] Oslo Lufthavn AS. (2011). Environmental report 2010. Retrieved from https://avinor.no/globalassets/_oslolufthavn/om-oslo-lufthavn/omoss/rapporter/en/environmental/Environmental-report2010.pdf.

[91] Oslo Lufthavn AS. (2012). Environmental report 2011. Retrieved from https://avinor.no/globalassets/_oslolufthavn/om-oslo-lufthavn/omoss/rapporter/en/environmental/Environmental-report2012.pdf.

[92] Oslo Lufthavn AS. (2013). Environmental report 2012. Retrieved from https://avinor.no/globalassets/_oslolufthavn/om-oslo-lufthavn/omoss/rapporter/en/environmental/Environmental-report2012.pdf.

[93] Oslo Lufthavn AS. (2014). Environmental report 2013. Retrieved from https://avinor.no/globalassets/_oslolufthavn/om-oslo-lufthavn/omoss/rapporter/en/environmental/environmental_report_20 13.pdf.

[94] Oslo Lufthavn AS. (2015). Environmental report 2014. Retrieved from https://avinor.no/globalassets/_oslolufthavn/om-oslo-lufthavn/om- 
oss/rapporter/en/environmental/environmental-report2015.pdf.

[95] Oslo Lufthavn AS. (2016). Environmental report 2015. Retrieved from https://avinor.no/globalassets/_oslolufthavn/om-oslo-lufthavn/omoss/rapporter/en/environmental/environmental-report2015.pdf.

[96] Oslo Lufthavn AS. (2017). Environmental report 2016. Retrieved from https://avinor.no/globalassets/_oslolufthavn/om-oslo-lufthavn/omoss/rapporter/en/environmental/environmental-report2016.pdf.

[97] Oslo Lufthavn AS. (2018). Environmental report 2017. Retrieved from https://avinor.no/globalassets/_oslolufthavn/om-oslo-lufthavn/omoss/rapporter/en/environmental/environmental-report2017.pdf.

[98] Oslo Lufthavn AS. (2019). Environmental report 2018. Retrieved from https://avinor.no/globalassets/_oslolufthavn/om-oslo-lufthavn/omoss/rapporter/en/environmental/environmental-report2018.pdf.

[99] Oslo Lufthavn AS. (2020). Environmental report 2019. Retrieved from https://avinor.no/globalassets/_oslolufthavn/om-oslo-lufthavn/omoss/rapporter/en/environmental/environmental-report2019.pdf.

[100] Oslo Lufthavn AS. (2021). Environmental report 2020. Retrieved from https://avinor.no/globalassets/_oslolufthavn/om-oslo-lufthavn/miljo-og-

lokalsamfunn/miljodokumenter/miljoarsrapport-2020engelsk.pdf.

[101] Preston, K. (2015). Sustainability initiatives helping airports address climate change. International Airport Review, 19(5), 16-19.

[102] Prosperi, D. (2009). Greening the world's airports. World Transport Policy \& Practice, 14(4), 48-56.

[103] Ramon Gil-Garcia, J. (2012). Enacting electronic government success: An integrative study of governmentwide websites, organizational capabilities, and institutions. New York, NY: Springer Science-Business Media.

[104] Reiss, B. (2007). Maximising non-aviation revenue for airports: Developing airport cities to optimise real estate and capitalise on land development opportunities. Journal of Airport Management, 1(3), 284-293.

[105] Remenyi, D, Williams, B, Money, A., \& Swartz, E A. (2010). Doing research in business and management: An introduction to process and method. London, UK: SAGE Publications.

[106] Ros, M. (2017). Why is Oslo Airport called the world's greenest? Retrieved from https://edition.cnn.com/travel/article/oslo-airport-worldsgreenest/index.html.
[107] Rossi Dal Pozzo, F. (2015). EU legal framework for safeguarding air passenger rights. Cham, Switzerland: Springer International Publishing.

[108] Sajed Sadati, S.M., Cetin, K., Ceylan. H., Sassani, A., \& Kim, S. (2018). Energy and thermal performance evaluation of an automated snow and ice removal system at airports using numerical modeling and field measurements. Sustainable Cities and Society, 43, 238250. https://doi.org/10.1016/j.scs.2018.08.021

[109] Scott, J. (2004). Documents, types of. In: M. Lewis-Beck, A.E. Bryman. \& T. Futing Liao (Eds.), The SAGE encyclopedia of social science research methods (pp. 281284). Thousand Oaks, CA: SAGE Publications.

[110] Scott, J. (2014). A dictionary of sociology (4th ed.). Oxford, UK: Oxford University Press.

[111] Scott, J. \& Marshall G. (2009). A dictionary of sociology (3rd ed.). Oxford, UK; Oxford University Press.

[112] Shulman, V.L. (2019). Tire recycling. In T. M. Letcher \& D. A. Vallero (Eds.), Waste: A handbook for management (pp. 489-515) (6th ed.). Amsterdam, The Netherlands: Elsevier.

[113] Simons, G.M. (2014). Airbus A380: A history. Barnsley, UK: Pen \& Sword Books.

[114] Staples, M.D., Malina, R., Suresh, P., Hileman, J.I., \& Barrett, S.R.H. (2014). Aviation $\mathrm{CO}_{2}$ emissions reductions from the use of alternative jet fuels. Energy Policy, 114, 342-354. https://doi.org/10.1016/j.enpol.2017.12.007

[115] Su, Y., Zhang, P., \& Su, Y. (2015). An overview of biofuels policies and industrialization in the major biofuel producing countries. Renewable and Sustainable Energy Reviews, 50, 991-1003. https://doi.org/10.1016/j.rser.2015.04.032

[116] Sukumaran, S., \& Sudhakar, K. (2017). Fully solar powered airport: A case study of Cochin International airport. Journal of Air Transport Management, 62, 176188. https://doi.org/10.1016/j.jairtraman.2017.04.004

[117] Sumathi, N., Phanendra, M.G.V.S., \& Teja, K.G. (2018). Green airports- Solution to stop pollution! International Journal of Latest Technology in Engineering, Management \& Applied Science, VII(IV), 78-85.

[118] Taber, C., \& Steele, B.A. (2020). Impact of HVLS fans on airplane hangar air destratification. ASHRAE Journal, April, 26-32.

[119] Taylor, J. (2011). Technology innovation and advance LEDs for airfield lighting. Retrieved from https://www.internationalairportreview.com/article/7451/t echnology-innovation-and-advance-leds-for-airfieldlighting/.

[120] The Avinor Group. (2021). About the company. Retrieved from https://avinor.no/en/corporate/about-us/the-avinorgroup/about-the-company.

[121] Thomas, C., \& Hooper, P. (2013). Sustainable development and environmental capacity of airports. In 
N.J. Ashford, H.P.M. Stanton, C.A. Moore, P. Coutu \& J.R. Beasley (Eds.), Airport operations (pp. 553-578) (3rd ed.). New York, NY: McGraw-Hill.

[122] United States Department of Energy. (2019) DOE BTO lighting R\&D program, 2019 Lighting R\&D Opportunities. $\quad$ Retrieved from https://www.energy.gov/sites/prod/files/2020/01/f70/sslrd-opportunities2-jan2020.pdf.

[123] United States Energy Information Agency. (2020). Solar explained: Solar energy and the environment. Retrieved from https://www.eia.gov/energyexplained/solar/solarenergy-and-the-environment.php

[124] Vestvik-Lunde, J. (2014). Oslo Airport achieves environmental management certification. Retrieved from: https://www.dnvgl.com/news/oslo-airport-achievesenvironmental-management-certification--7403.

[125] Wang, C., \& Prinn, R.G. (2010). Potential climatic impacts and reliability of very large-scale wind farms. Atmospheric Chemistry and Physics, 10(4), 2053-2061.

[126] Warren, C.R., Lumsden, C., O’Dowd, S., \& Birnie, R.V. (2005). 'Green On Green': Public perceptions of wind power in Scotland and Ireland. Journal of Environmental Planning and Management, 48(6), 853-875. https://doi.org/10.1080/09640560500294376

[127] Wejden B., \& Øvstedal J. (2006). Contamination and degradation of de-icing chemicals in the unsaturated and saturated zones at Oslo Airport, Gardermoen, Norway. In J.H. Tellam, M.O. Rivett, R.G. Israfilov \& L.G. Herringshaw (Eds.), Urban groundwater management and sustainability (pp. 205-218). NATO Science Series (IV: Earth and Environmental Sciences), Vol 74. Dordrecht, The Netherlands: Springer, Dordrecht.

[128] Yildiz, O.F., Yilmaz, M., \& Çelik, A. (2021). Energy analysis of cold climate region airports: A case study for airport terminal in Erzurum, Turkey. International Journal of Sustainable Aviation, 7(1), 66-92

[129] Yin, R.K. (2018). Case study research and applications (6th ed.). Thousand Oaks: SAGE Publications.

[130] Young, S.B., \& Wells, A.T. (2011). Airport planning \& management (6th ed.). New York, NY: McGraw Hill. 